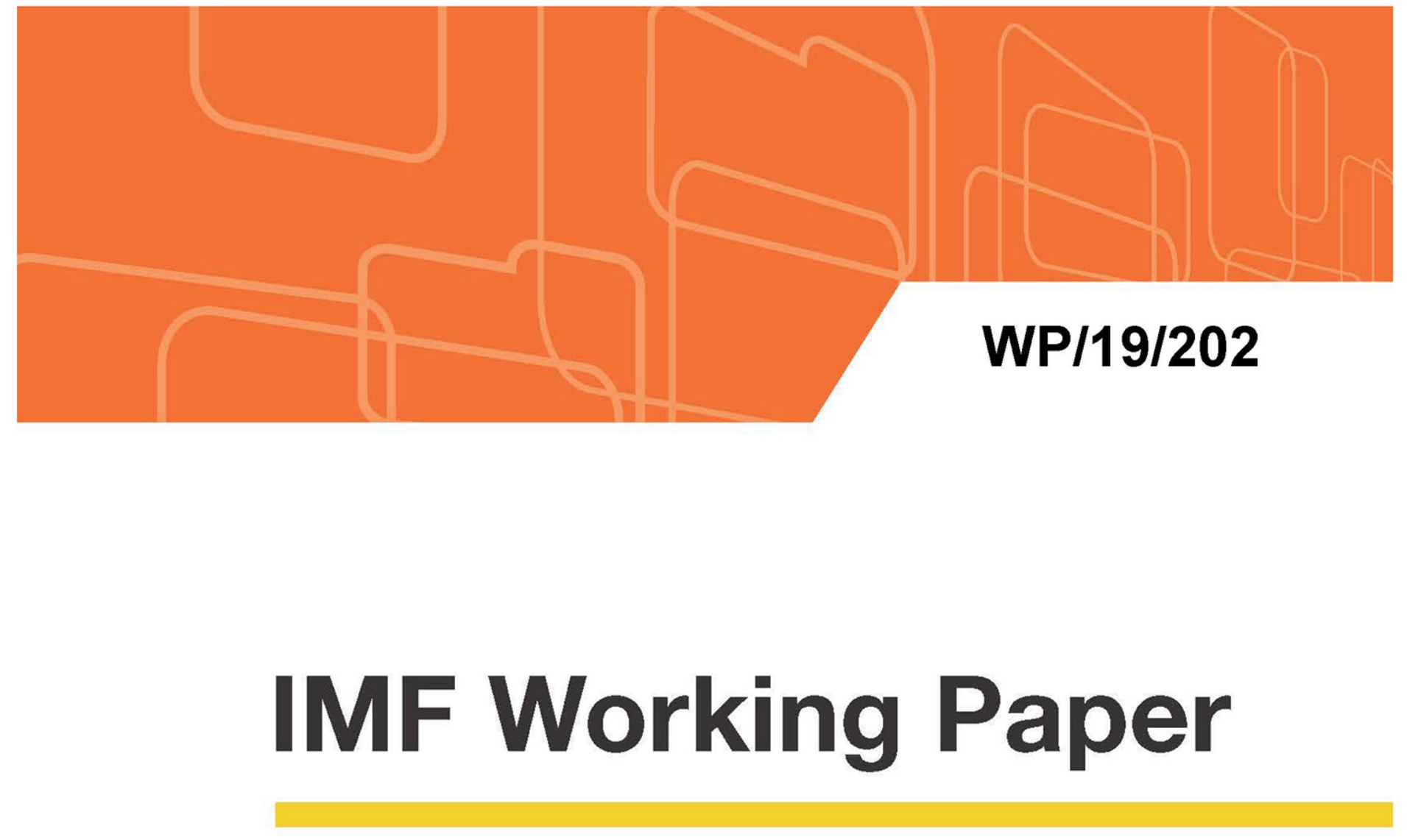

\title{
One Ring to Rule Them All? New Evidence on World Cycles
}

by Eric Monnet and Damien Puy

\begin{abstract}
IMF Working Papers describe research in progress by the author(s) and are published to elicit comments and to encourage debate. The views expressed in IMF Working Papers are those of the author(s) and do not necessarily represent the views of the IMF, its Executive Board, or IMF management.
\end{abstract}




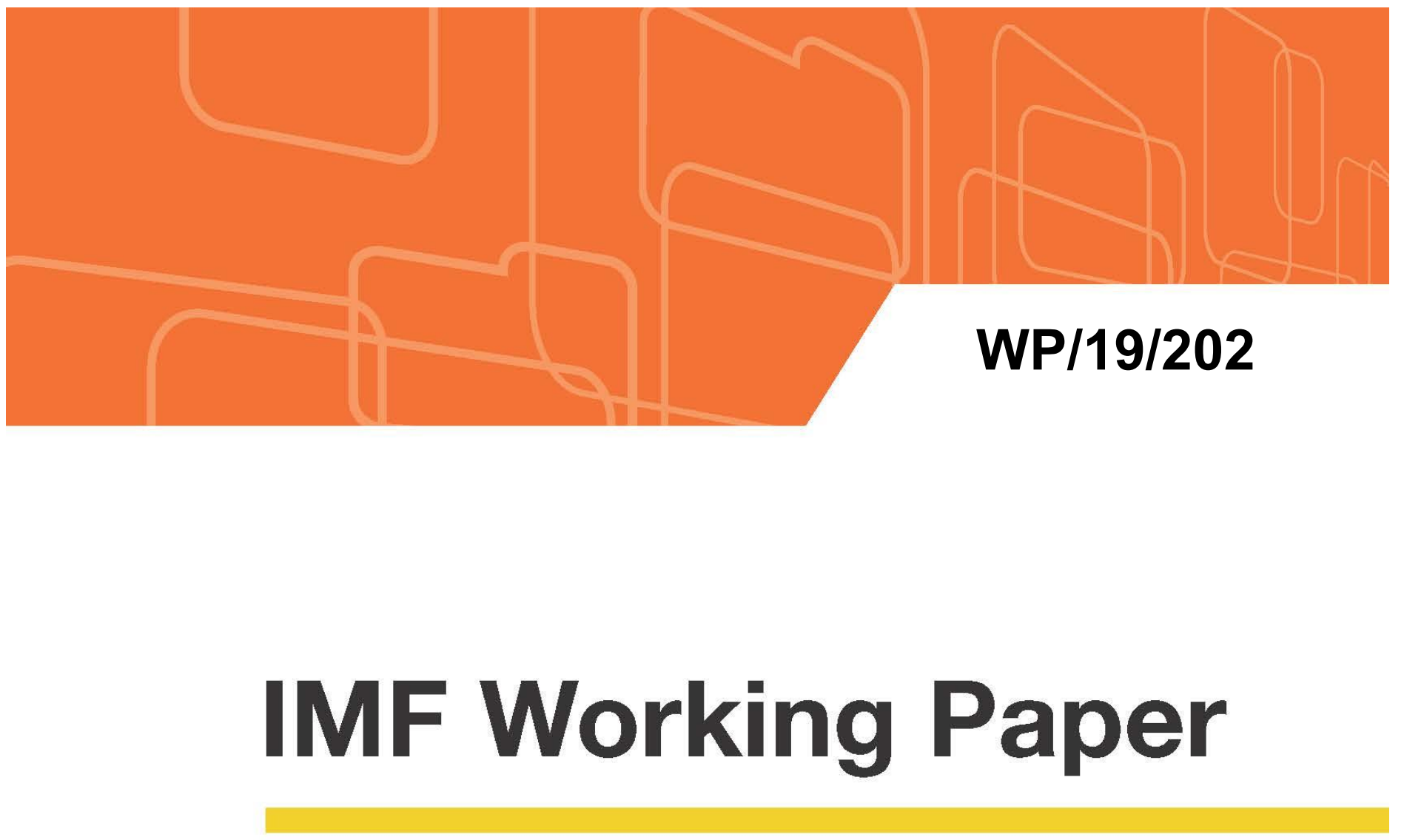

\title{
One Ring to Rule Them All? New Evidence on World Cycles
}

by Eric Monnet and Damien Puy

\begin{abstract}
IMF Working Papers describe research in progress by the author(s) and are published to elicit comments and to encourage debate. The views expressed in IMF Working Papers are those of the author(s) and do not necessarily represent the views of the IMF, its Executive Board, or IMF management.
\end{abstract}

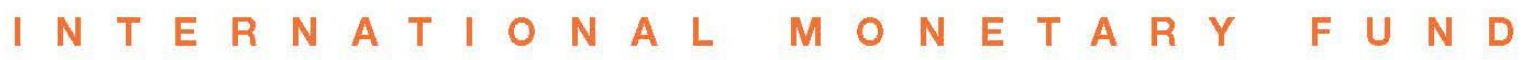




\title{
IMF Working Paper
}

\author{
Research Department
}

\section{One Ring to Rule Them All? New Evidence on World Cycles \\ Prepared by Eric Monnet and Damien Puy ${ }^{1}$}

\author{
Authorized for distribution by Maria Soledad Martinez Peria \\ September 2019
}

\begin{abstract}
IMF Working Papers describe research in progress by the author(s) and are published to elicit comments and to encourage debate. The views expressed in IMF Working Papers are those of the author(s) and do not necessarily represent the views of the IMF, its Executive Board, or IMF management.
\end{abstract}

\begin{abstract}
We estimate world cycles using a new quarterly dataset of output, credit and asset prices assembled using IMF archives and covering a large set of advanced and emerging economies since 1950. World cycles, both real and financial, exist and are generally driven by US shocks. But their impact is modest for most countries. The global financial cycle is also much weaker when looking at credit rather than asset prices. We also challenge the view that syncronization has increased over time. Although this is true for prices (goods and assets), this not true for quantities (output and credit). The world business and credit cycles were as strong during Bretton Woods (1950-1972) as during the Globalization period (1984-2006). For most countries, the way their output co-moves with the rest of the world has changed little over the last 70 years. We discuss the reasons behind these new findings and their policy implications for small open economies.
\end{abstract}

\section{JEL Classification Numbers: E32, F41, F42}

Keywords: World Cycles, Business Cycles, Financial Cycles, Financial integration, Trade integration, Globalization, US Monetary Policy.

Author's E-Mail Addresses: eric.monnet@banque-france.fr, dpuy@,imf.org

\footnotetext{
${ }^{1}$ The views expressed in this paper are those of the authors and do not represent the views of the IMF, the Banque de France or the Eurosystem. We thank seminar participants at the Bank of International Settlements, CEBRA IFM conference at the Bank of England, IMF Research department and the $2^{\text {nd }}$ Annual Macro-Financial Research Conference for comments and suggestions. We are grateful to Giovanni Dell'Ariccia, Soledad Martinez Peria, Deniz Igan, Egon Zakrajsek, Alessandro Rebucci and Anton Korinek for useful discussions. Some of the material in this paper builds on the following working paper by the same authors ("Has Globalization Really Increased Business Cycle Synchronization?"). Major improvements and data addition have been made with respect to the old version.
} 


\section{CONTENTS}

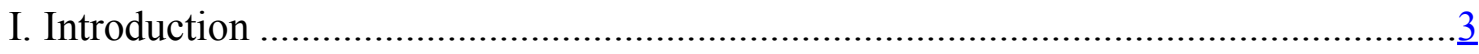

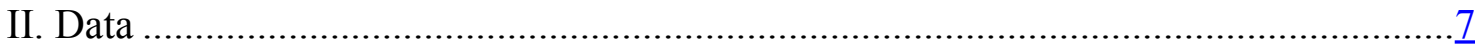

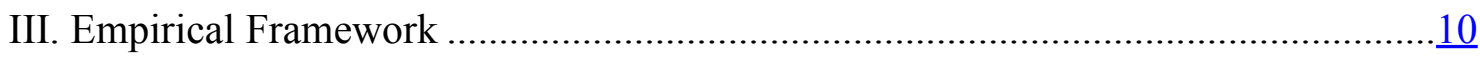

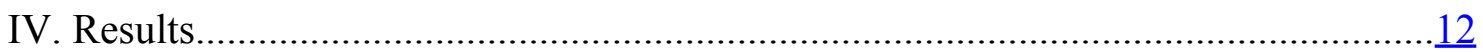

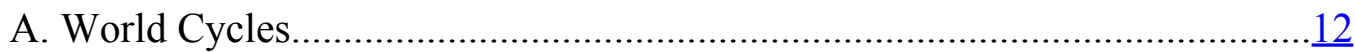

B. The US and World Cycles........................................................................14

C. How Strong are World Cycles? And Has it Changed? ..................................17

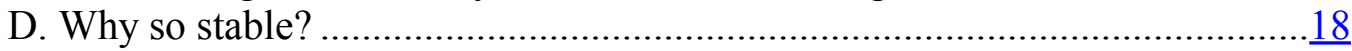

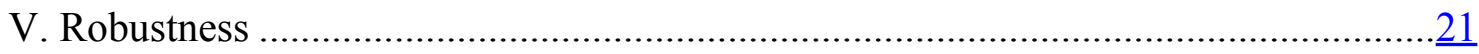

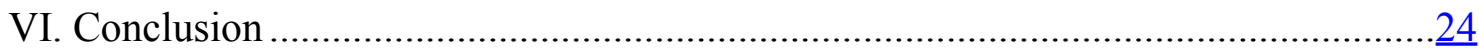

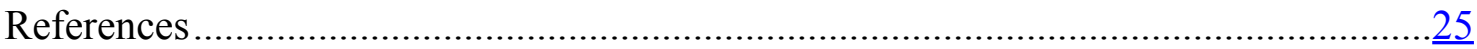

TABLE

1. Determinants of World Business Cycle Synchronization...........................................21

FIGURES

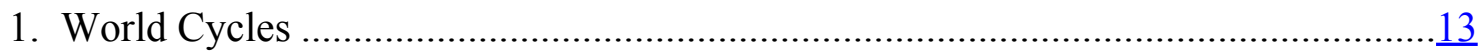

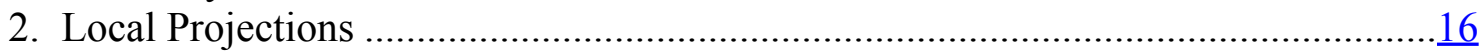

3. Strength - Full Sample .............................................................................17

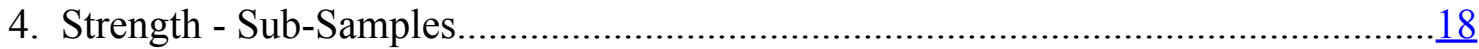

5. Output synchronization with the World - Then and Now......................................

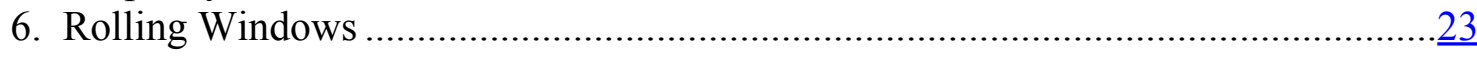

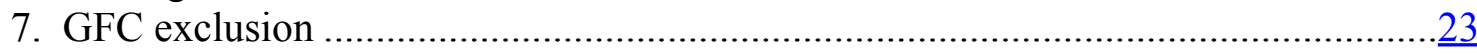

Appendices

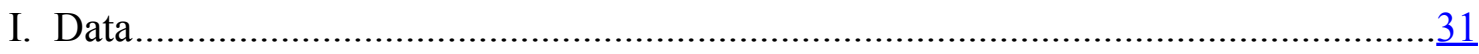




\section{INTRODUCTION}

Do world cycles really exist? And if so, how strong are they? Over the last two decades, empirical evidence on world cycles - both real and financial - has been increasing. ${ }^{2}$ Although this issue has been approached from various angles, a consensus seems to have emerged around three facts. First, world cycles exist and are driven by the US, and in particular by US monetary policy. ${ }^{3}$ Second, their effect is quantitively strong. ${ }^{4}$ They affect both real and financial variables, quantities and prices. Isolating your economy from them is, at best, a challenging task (Rey (2013, 2015)). Third, their strength has increased over time, mainly because of the intense globalization process that started in the mid-80's..$^{5}$ Taken together, these facts have portrayed world cycles as a dominating force and weighed on some important policy debates. They have pushed the view that integration - both real and financial - comes at the cost of increased synchronization, even in normal times. They also suggest that the degree of control over domestic variables (or policy autonomy) is limited, especially in small open economies that have chosen to integrate their economies into the global market.

We revisit this conventional wisdom using a new high-frequency dataset of output, consumer prices (CPI), credit and asset prices (stock prices and bond yields) for a large sample of advanced and emerging countries since 1950. Building on the unique history of the International Monetary Fund (IMF) as a hub for international statistics, we create new long macro-financial series using the paper archives of the IMF International Financial Statistics (IFS). Extracting information that was never previously digitalized, we are able to recreate the real and financial (statistical) profile of most emerging and advanced economies over the whole post-war period at a quarterly frequency. To our knowledge, we are the first to assemble a quarterly

\footnotetext{
${ }^{2}$ See, among others, Kose, Otrok and Whiteman (2003) on the world business cycle, Miranda-Agrippino and Rey (2015) on the global financial cycle and Auer et al. (2017) on the world inflation cycle. In what follows, we use "global" or "world" interchangeably.

${ }^{3}$ See Ammer et al. (2016) for a review of US monetary policy spillovers. Recent evidence on the effect of US policy on financial variables include Miranda-Agrippino and Rey (2015), Jorda et al. (2019) and references therein. See Brauning and Ivashina (forthcoming) and Cerutti et al. (2017) for evidence on capital flows.

${ }^{4}$ The various literatures report a quantitively significant impact of world cycles on domestic variables. Auer et al. (2017) find that a global inflation factor explains 50 percent of local inflation dynamics. Miranda-Agrippino and Rey (2015) and Kose et al. (2003) report that an important share of variance in domestic asset prices (or output) can be explained by a global factor.

${ }^{5}$ Evidence of a rise in global output co-movement include, inter alia, Lumsdaine and Prasad (2003), Kose, Prasad and Terrones (2003), and Kose, Otrok and Whiteman (2008). On the financial side, see Cesa-Bianchi et al. (2019) or Jorda et al. (2019). Ha. et al (2019) and references therein also report a rise in inflation synchronization.
}

(continued...) 
dataset with such a long and wide coverage. ${ }^{6}$ More importantly, we correct several issues related to the coverage, frequency and quality of existing macro-financial datasets, which have ultimately biased the perception of world cycles.

Building on standard econometric tools used in the literature (i.e. dynamic factor models), we first confirm several findings. We find that world cycles, both real and financial, exist. We estimate very precise world cycles in all variables output, credit, inflation and asset prices - over the whole post-war period. However, those factors do not always correlate, implying that financial variables (domestic credit, equity prices and bond yields) respond to different global forces (Jorda et al., 2019). We also confirm that the US seems to be the main driver of global dynamics, both real and financial. More precisely, we find that US shocks typically identified in the literature, such as monetary policy shocks, fiscal policy shocks or policy uncertainty shocks, drive real and financial world cycles. Qualitatively, this confirms the role of the US hegemon (Miranda-Agrippino and Rey (2015)).

We also challenge important results, however. First, we qualify the quantitative importance of world cycles. In line with the existing literature, our estimates confirm that world cycles have been an important source of volatility for domestic variables over the postwar period (1950-2015). Their strength, however, varies significantly with the sample used (time, country and variable). In general, the strength of world cycles - measured by the share of the variance of domestic variables explained by the world dynamics - drops significantly when "extreme" observations are excluded from the sample (e.g. the oil shocks or the 2008/2009 financial crisis) and/or when looking at emerging markets (EMs). We also find that world cycles are much stronger when looking at prices (consumer goods and assets) rather than quantities (output and credit). In normal times, the impact of the world business cycle on domestic output is relatively modest (around 15 percent for the median country). The strength of the global financial cycle depends heavily on the variable used: synchronization is three to four times higher when using stock and bond prices (around 50 percent) rather than credit (around 10-15 percent). Overall, world cycles disproportionately affect advanced economies and/or asset prices.

We also challenge the view that world synchronization has increased over time. Although the synchronization of asset (and goods) prices has increased steadily over the last seven decades, this is not true for output and credit. The world output and credit cycles were as "strong" during Bretton Woods (1950-1971), a low point of financial and trade integration, as during the Globalization period

\footnotetext{
${ }^{6}$ The dataset will be made available on authors' websites, along with a complete compilation guide and a comparison with other datasets.
} 
(1984-2006). World cycles explain roughly 15 percent of the variance in domestic credit and output for the median country, and below 10 percent for the median emerging market in both periods. After the Global Financial Crisis (GFC), output and credit synchronization has also reverted to relatively low historical levels. In contrast, synchronization in prices (assets and goods) has roughly doubled since Bretton Woods (from 25 percent to 50 percent for the median country) and has not decreased since the GFC. In other words, although higher asset price synchronization seems to be a new feature of the international financial system, we do not find robust evidence of increased output and credit synchronization.

Finally, we explore the factors behind the stability of output synchronization over the last 70 years. We show that this is the result of two opposing forces - trade and financial integration - that have left the average level of output synchronization in the world roughly unchanged. Countries that have increased their trade integration more than others have also synchronized their domestic output with the world business cycle. However, financial integration had the opposite effect. Countries that have deepened their financial linkages with the world have de-synchronized their output from the world cycle. This result is reversed only during the GFC, during which more financially open countries have experienced more output synchronization with the world. The flexibility of the exchange rate, however, has not affected the extent to which domestic economies react to the global dynamics.

This paper makes several important contributions. The first is a significant increase in macro-financial data available to researchers. Although the academic (and policy) interest for global macro-financial dynamics has soared since the GFC, important data gaps remain. Broadly speaking, our data addresses three shortcomings. We first increase the frequency of long/historical macro-financial datasets, which are usually available at annual frequency (e.g. Jorda et al. (2017)). Besides washing out small and short-lived cycles, using annual data prevents time comparisons because the amount of data is not enough to re-estimate models on sub-samples. Second, we address a longstanding problem of country coverage. Because of data constraints, long evidence on world cycles is usually neither "long" (i.e. limited to post-1990's) nor about the "world" (i.e. limited to advanced countries). ${ }^{7} \mathrm{We}$ solve this issue by improving considerably the statistical coverage of both advanced and emerging markets before the early 1990's. This allows, for

\footnotetext{
${ }^{7}$ Long historical comparisons based on quarterly data are almost exclusively focused on G7 countries (Kose, Otrok and Whiteman (2008), Doyle and Faust (2005), Ha et al. (2017)). Studies with a broader geographical focus are constrained to the post 90's because of data constraints in EMs and smaller advanced economies (e.g. Miranda-Agrippino and Rey (2015)). Our data alleviates this tradeoff.
} 
the time, to compare the macro-financial behavior of most countries both before and after their integration into world markets. We are also able to identify truly "world" cycles, as opposed to "regional" cycles (or cycles affecting only advanced countries). The third contribution is the addition of long credit data, especially in EMs, which allows us to paint a much more accurate picture of the financial cycle. ${ }^{8}$ Using a more complete statistical picture reveals that part of the conventional wisdom on world cycles comes from a measurement problem. Because of data constraints, the literature has focused its attention on (i) advanced economies (ii) the very recent past (post 1990's) and (iii) prices (especially asset prices) rather than quantities. This practice has given too much weight to specific groups of countries (e.g. G7), abnormal times (e.g. the GFC) and/or variables (e.g. equity prices), and ultimately led to an over-estimation of the strength (or increase in strength) of world cycles, both real and financial.

Our results also provide evidence on the way financial and trade linkages connect domestic output to the world. The synchronizing effect of trade is in line with the literature documenting the positive impact of trade integration on bilateral output correlations. ${ }^{9}$ Similarly, the strong and asymmetric impact of financial integration we identify echoes the recent literature investigating the impact of finance on bilateral co-movement. ${ }^{10}$ Our findings show that financial and trade integration affects not only country-pairs co-movement patterns, but more generally the way countries co-move with the rest of the world. To our knowledge, we are the first to identify this effect over such a long period of time. The absence of a role for the exchange rate regime as a determinant of a country's synchronization with the rest of the world is also in line with other contributions (Miranda-Agrippino and Rey (2015), Dedola et al. (2016)) and generally support the presence of a dilemma rather than a trilemma.

Our findings also have important policy implications. A straightforward corollary of our results is that a low level of financial integration does not imply, per se, a low level of co-movement in the economic system. Contrary to conventional wisdom and previous studies (Williamson 1985), the Bretton Woods

\footnotetext{
${ }^{8}$ Existing credit series are usually annual and limited to advanced economies (Jorda et al. (2017)). Usually, those series are also not corrected for breaks. Long (quarterly) credit statistics with break adjustments are provided by the Bank for International Settlements (BIS), but their coverage is very uneven across country and time. The lack of clean and balanced credit series explains the scarcity of existing work on credit cycles (compared to asset prices). We extend the BIS approach to new archival data, which allows us to fill the remaining gaps in cross-cournty credit statistics (see below).

${ }^{9}$ For a recent review and discussion of (theoretical and empirical) channels, see Duval et al. (2015).

${ }^{10}$ See Kalemli-Ozcan, Papaioannou and Perri (2013), Kalemli-Ozcan, Papaioannou and Peydro (2013) and Duval et al. (2015) and Cesa-Bianchi et al. (2019). For a model where financial integration reduces the international correlations in GDP see, for instance, Heathcote and Perri (2004).
} 
period was also affected by world cycles, although capital controls were still the norm and financial systems were highly regulated. Conversely, a high level of international financial integration does not always imply stronger output comovement. In fact, in the long run and absent major global financial crisis, we find that international financial integration has reduced global output co-movement. Although contagion effects can dominate (as exemplified by the GFC), the focus on the last financial crisis has painted a biased picture and has ignored some of the de-synchronizing effects finance has had during the 20 years leading to the GFC.

Finally, the modest impact of the world cycles on domestic output and credit provides perspective on the degree of (or lack thereof) policy autonomy, especially in EMs. Outside periods of global (real or financial) shocks, we find that world cycles have had a modest impact on key policy targets, i.e. output and credit. Looking at credit in particular, a financial variable that is more macro-critical and under more direct control of policymakers than asset prices, clearly suggests that local credit conditions for the private sector are not directly tied to the external environment (or to US conditions). In our sample, this finding is especially true for EMs. Although this does not mean that US shocks do not have an impact on local credit conditions in EMs, it provides perspective on the macro relevance of some the effects previously identified in the literature, a point we discuss in the last section.

The remainder of this paper is constructed as follows. Section II goes over the key features of the dataset. More technical details are reported in Appendix. Section III presents the empirical framework. Section IV presents key results. Section V discusses extensions and robustness checks. Section VI concludes.

\section{DATA}

An important contribution of this paper is to assemble a new "long" macrofinancial dataset of output, credit and prices (assets and goods) covering (i) a wide range of advanced and emerging countries (ii) over the whole post-war period and

(iii) at quarterly frequency. To do so, we make extensive use of the International Financial Statistics (IFS) paper volumes, which contain the whole history of statistical information published by the IMF ever since its creation. Since 1944 and as part of the Bretton Woods agreement, the IMF requires that its members send standard macro-financial statistics at a high frequency (in particular price, trade, reserve and credit statistics). Over time, the IMF has therefore become the leader of data collection and dissemination among international organizations, and the 
main provider of macro-financial data to academic circles (through IFS). ${ }^{11}$ However, for various institutional and historical reasons, only a small part of the information compiled in IFS has made it to the official "digital" version of the IFS database. Our main contribution is to tap directly into the IFS paper volumes, stored in the IMF Archives, to recover the statistical information over the last 70 years, for both advanced and emerging countries.

We construct five variables for a large cross section of countries: (i) GDP, (ii) Credit, (iii) Consumer Prices, (iv) Stock Prices, and (v) Long-term Bond Yields. Although some specificities apply, we follow the same procedure for all series. ${ }^{12}$ We first collect official statistics online, from IFS online or national statistical institutes, for each variable and then use the IFS archives to extend all series in the past, after making sure definitions match. ${ }^{13}$ For consumer prices, stock prices and bond yields, this exercise is straightforward and generally amounts to collecting data directly from old vintages of IFS. ${ }^{14}$ The exercise is more involved for real quarterly GDP, which have been compiled and published only recently, and credit aggregates, which are subject to a significant number of breaks throughout history. ${ }^{15}$ For GDP, we use temporal disaggregation methods (Chow Lin, 1971) to create "synthetic" quarterly GDP series based on annual GDP series and historical quarterly Industrial Production (IP) data. This method, which tracks actual quarterly GDP very accurately, is widely applied in countries in which quarterly data (or surveys) are expensive and IP is the only reliable indicator of highfrequency output fluctuations. ${ }^{16}$ It is also a standard tool used by international organizations (e.g. the OECD) to generate long quarterly GDP data when long official quarterly data are missing. ${ }^{17}$ When breaks in credit series happen, those

\footnotetext{
${ }^{11}$ The OECD is the only other institution with a similar mandate, but its country and data coverage is much more limited than the IMF and does not really focus on international financial data. OECD data also has a shorter coverage (it was created only in 1961).

${ }^{12}$ See appendix for a complete description of the variables (compilation, definition etc.).

${ }^{13}$ To be more precise, we check that definitions match (on paper) and that they report the same variations (i.e. IFS statistics and Official Statistics match de facto when both are available).

${ }^{14}$ Changes in definitions and collection methods over time are minimal for these categories.

${ }^{15}$ Breaks happen very frequently due to (i) changes in the definition and scope of banks and/or the private sector or (ii) changes in accounting standards, by the local central banks or by the IMF. See appendix for more details.

${ }^{16}$ This procedure is actually recommended in the IMF Quarterly National Accounts Manual. We discuss the performance of temporal disaggregation methods in Appendix.

${ }^{17}$ Even in advanced countries, official quarterly GDP series usually start after the mid-1990's. We come back to this issue below.
}

(continued...) 
breaks are well-documented in the IFS volumes and, at least for a couple quarters, both values of the same data series are reported under the old and the new definition. This allows us to chain different data series and create long series without breaks.

Besides extending the country and time coverage of existing datasets, our methodology also improves the quality of historical GDP and credit series. Since very few national statistical institutes (even in most OECD countries) publish quarterly GDP data before 1990, international organizations generally rely on interpolations to produce quarterly GDP statistics, which are in turn used by researchers. ${ }^{18}$ However, those interpolations are not always based on actual output data (e.g. industrial or manufacturing production). Using historical IP data directly sourced from the IFS archives therefore eliminates GDP series based on simple linear interpolations that are still present in widely used international macroeconomic databases. ${ }^{19}$ Similarly, we solve issues related to the compilation of credit data, which have generally received less attention, even though most of the credit received by the private sector in both AEs and EMS still goes through banks. In line with the BIS long credit dataset (Dembiermont, 2013), we use different vintages of the same data to fix the breaks..$^{20}$ The use of IMF paper archives therefore allows us to extend the BIS approach and fill the remaining gaps in historical credit statistics.

Finally, using IFS as a single source also ensures that definitions of variables are consistent and continuous across time and countries, a potential issue that emerges when datasets from different organizations are merged. ${ }^{21}$ Although efforts have been made to improve the coverage of macro-financial data (e.g. GDP

\footnotetext{
${ }^{18}$ With the exception of a few countries (e.g. the US, France or the UK), long official quarterly GDP statistics do not exist, or start very late (mid 90's). For example, official quarterly GDP series for European countries compiled and published by Eurostat start in 1995. Long output statistics are therefore estimated using various methods by the OECD, such as temporal disaggregation methods. See appendix for more details.

${ }^{19}$ The issue of long (quarterly) real GDP data has been raised in recent papers. For example, Romer and Romer (2017) use OECD quarterly real GDP data since 1967 but emphasize that such series are "less consistent in both quality and methodology across countries". For this reason, they use industrial production which is straightforward to measure and more reliable to assess the effect of crises on business cycles. The large and influential literature on the effects of US monetary policy often relies on industrial production series (Bernanke and Mihov 1998, Romer and Romer 2004, Barakchian and Crowe 2013). In our case, we combine annual GDP number, which are well established and quarterly IP data.

${ }^{20}$ When breaks in definition are too substantial, credit series were not extended. A complete description of definitions and breaks is provided in the compilation guide available on the authors webpages.

${ }^{21}$ This explains why the archives (or more generally the original publications of the IMF) have been used extensively by economic historians to study the history of exchange rate arrangements or financial liberalization (Calvo \& Reinhart 2002, Reinhart and Rogoff 2004, Chinn \& Ito 2006, Quinn \& Toyoda 2008). The IMF Direction of Trade Statistics, which provides annual data since 1948, also forms the basis of the trade literature about trade and gravity models. To some extent, we extend this practice to macro and financial data.
}

(continued...) 
by the OECD, Credit statistics by the BIS etc.), the overlap between datasets can be poor. ${ }^{22}$ Although we are not able to get all the data for all countries, our dataset significantly improves the overlap across variables, resulting in a much more balanced panel than usual.

Table 1 (in appendix) summarizes the final coverage of our dataset for each of the five variables collected, namely (i) output, (ii) credit, (iii) prices, (iv) stock prices, and (v) long-term bond yields. All series are available at quarterly frequency and follow standard definitions. Output refers to quarterly GDP. In line with BIS and other major contributions on credit cycles (e.g. Claessens, Kose and Terrones (2011), Jorda et al (2017)), "credit" denotes the stock of domestic bank credit to the private non-financial sector, expressed in local currency. Prices refers to the Consumer Price Index (CPI in short). The stock price is an index tracking the prices of common shares traded on the main stock exchange. Long-term bond yield reports the yield observed on government bonds maturing in 7 to 10 years, depending on the country. Details about definitions and compilations are reported in the appendix.

Quantitatively, we cover (i) 37 countries for GDP (21 AEs and 16 EMs), (ii) 45 countries for credit (21 AEs - $24 \mathrm{EMs),} \mathrm{(iii)} 50$ countries for prices, (21 AEs - 29 EMs), (iv) 27 countries for stock prices (20 AEs and 7 EMs), and (v) 17 countries for bond yields (16 AEs and 1 EM) ${ }^{23}$ Compared to existing datasets, we increase the data coverage by around 20 to 30 percent for advanced economies, depending on the series. Gains in coverage, however, are generally much higher for emerging markets. We roughly double the amount of data available for output and credit (compared to OECD and BIS data, respectively) and increase it by 50 percent for stock prices (compared to IFS online). The smallest increase is for bond yields in emerging markets. We cover only one emerging market (South Africa) throughout the period.

\section{EMPIRICAL FRAMEWORK}

In line with most of the empirical literature, we use a dynamic factor model to estimate world cycles and quantify their impact on the variance of individual series in each country. Since we focus exclusively on co-movement at the world level, we restrict attention to a single factor model in the spirit of Stock and Watson (1989, 1991):

\footnotetext{
${ }^{22}$ For instance, long and high-quality credit statistics are available from the BIS for some emerging markets (e.g. Argentina or Thailand since the 1950's), but prices or output data are not. Conversely, some countries with good coverage from the output side do not have any information on the financial side.

23 Those numbers correspond to countries with "full coverage", i.e. going at least to 1957Q1. Most of them have coverage going back until 1950Q1, however.
} 


$$
\begin{gathered}
Y_{i, t}=P_{i} F_{t}+u_{i, t} \\
F_{t}=A_{1} F_{t-1}+A_{2} F_{t-2}+\cdots+v_{t} \\
u_{i, t}=C_{1} u_{i, t-1}+C_{2} u_{i, t-2}+\cdots+e_{i, t}
\end{gathered}
$$

Where $Y_{i, t}$ designates the variable to be explained (e.g. output or credit) in country $i$ in quarter $t$ and $F_{t}$ is the world factor at time $t$. In practice, we use an AR (1) in both the factor and the error term, and estimate the model using Maximum Likelihood. All variables are computed in yearly growth rates, except for bond yields, which are computed in yearly absolute difference (since they are already expressed basis points). We rely on this empirical framework because of its simplicity and low computational cost. However, results are very robust to alternative approaches. For instance, our findings are not sensitive to the number of lags in the AR processes. Results are also invariant to other factor extraction methods, such as estimations of the factors with Bayesian methods and/or with inclusion of additional factors (e.g. regional factors). For instance, using a model in the spirit of Kose, Otrok, and Whiteman (2003) yields identical results to the ones presented below. ${ }^{24}$

Building on the longer coverage of the database, we estimate the factor model and variance decompositions for each series separately (e.g. GDP) on the full sample. Variance decompositions are then estimated on four different subperiods: the Bretton Woods period (1951 Q1-1971 Q4), the oil shock period (1972 Q1-1983 Q4), the globalization period (1984 Q1- 2006 Q4), and the financial shock (or GFC) period (2007 Q1-2015 Q4). We use this decomposition for several reasons. First, we isolate periods of global shocks to assess the sensitivity of results to outliers, or periods of extreme co-movement. Although these periods are important to consider, they also weigh heavily on the results and policy conclusions. ${ }^{25}$ Second, debates about the role of globalization (trade or financial) revolves around the comparison of world synchronization before and after the kink in the "hockey-stick" of globalization, which is usually dated around 1985 (Jorda et al, 2017). For the first time, we are therefore able to compare the intensity of comovement under "normal" macroeconomic fluctuations (i.e. without extreme shocks) under low integration (1951 to 1971) to its counterpart under deep

\footnotetext{
${ }^{24}$ Results available on request.

25 The decade ranging from 1973 to 1983 features the demise of the Bretton Woods system, two inflationary oils shocks and, as a result, the widespread use of contractionary monetary policy in almost all advanced economies starting 1979. Similarly, the period from 2007 to 2014 was characterized by the GFC and the European debt crisis. Including these outliers in a sub-period rather than another can change findings drastically. For instance, including the oil shocks in the "globalization" period generally drives the result that output synchronization has increased over time.
} 
integration (1985 to 2006). ${ }^{26}$ Third and finally, isolating periods of global shocks allows us to test whether the effect of trade or financial integration varies with the type of shocks hitting the world economy (real shocks in the 1970s or financial shock in 2008-2009). We come back to this issue in the next section.

\section{Results}

\section{A. World Cycles}

Figure 1 reports the world cycles extracted on each variable namely (i) Output (ii) Credit (iii) Stock Prices (iv) Bond Yields and (i) Prices (inflation), along with confidence intervals (5 percent and 95 percent). All variables are expressed as yearly growth rates - with the exception bond yields which are expressed as yearly absolute changes - and expressed in real terms. Values are expressed in deviations from the (long run) sample mean and can therefore take negative values for a relatively long time. ${ }^{27}$

Overall, we find that all factors are well estimated over the whole period. Peaks and troughs are also in line with major real and financial expansions (or crisis). ${ }^{28}$ The factors are also in line with existing studies which have estimated them using yearly data (e.g. Kose et al (2003), Auer et al. (2017)). Two facts are worth mentioning however. First, the output and credit cycles are strongly correlated (the contemporaneous correlation is 0.87 ). However, this correlation is much lower for all other pairs of cycles (which range between 0.1 and 0.3 ). Among other things this confirms that financial variables respond to different underlying global factors. Second, we find that variations in asset prices (bond yields and stock prices) are generally more frequent than movements in quantities. Credit cycles are, in particular, much more protracted than asset prices cycles.

\footnotetext{
${ }^{26}$ The Bretton Woods sample (1950-1971) is notable for its steady growth and stable business cycles dynamics, whereas the Globalization period (1984-2006) captures most of the Great Moderation. In addition, both periods are almost of equal length. This decomposition is also in line with Kose, Otrok and Whiteman (2008), which facilitates comparisons of our results with theirs.

${ }^{27}$ For instance, growth and inflation around the world were not negative (on average) in the post 90 's. They were simply below the long run mean of the data.

${ }^{28}$ In an older version of this paper dedicated only to output (Monnet and Puy, 2016), we conducted a narrative analysis of the world output cycle based on the IMF annual reports published between 1950 and 2014 and find that the world cycles described in IMF reports match almost exactly the turning points and phases identified by our estimation procedure. Results available on request.
} 
Figure 1: World Cycles
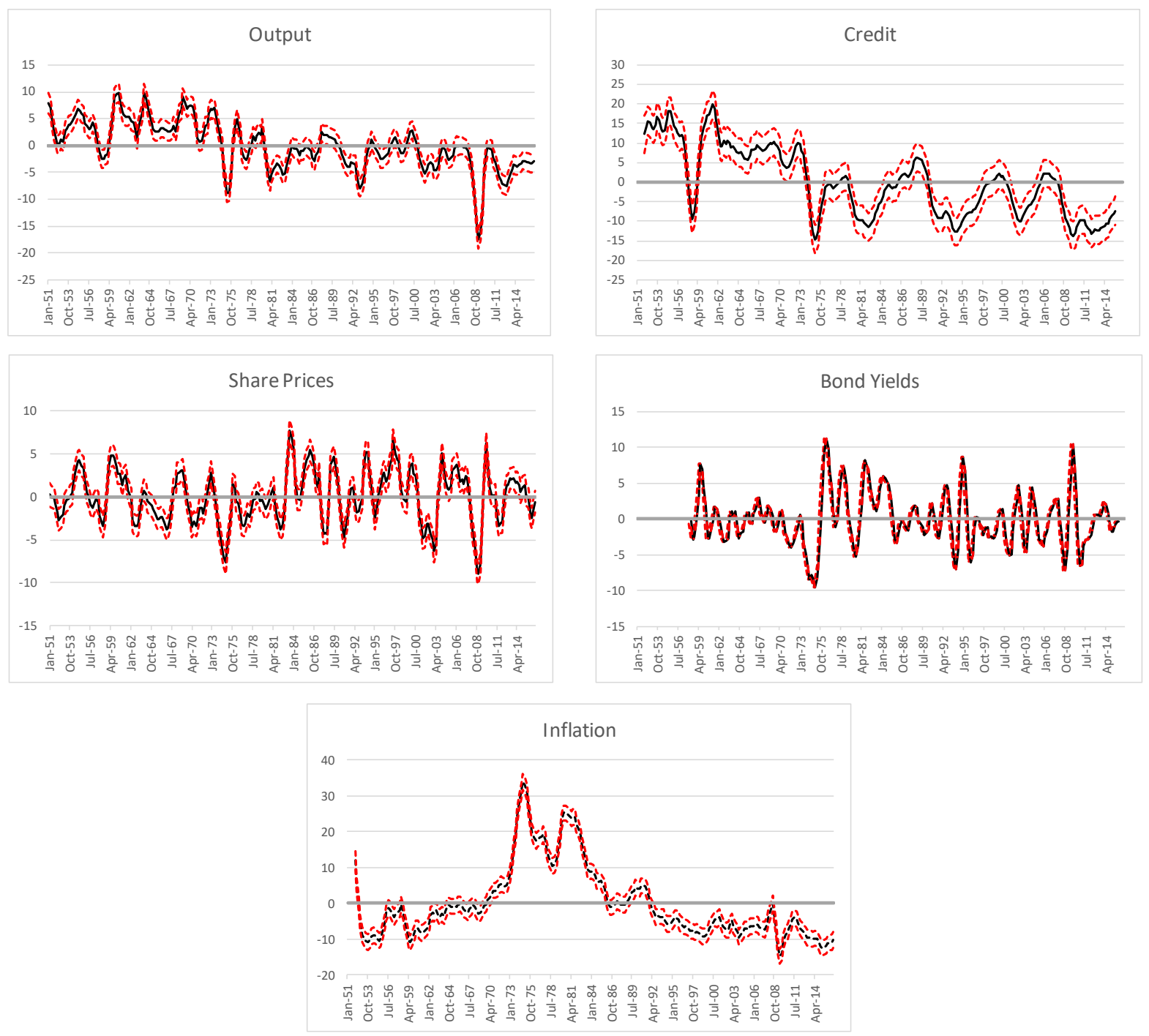

Note: The figures plot the results of the factor estimations $\left(F_{t}\right)$ for each variable (solid black lines). Dotted lines plot confidence intervals. Output refers to yearly output growth (in \%); credit to real y-o-y credit growth (in \%); stock prices to real y-o-y stock price growth (in \%), Bond yields to y-o-y change in real bond yields (in bps); Inflation to yearly CPI inflation. 


\section{B. The US and World Cycles}

Is the US ruling over the world? To assess whether the US "drives" world cycles, both real and financial, we follow Miranda-Agrippino and Rey (2015) and check to what extent changes in US variables affect world cycles. In practice, we collect externally identified US shocks and assess the response of our (estimated) world cycles to those shocks using Jorda's local projection framework (Jorda, 2005). In practice we estimate the following model:

$$
\Delta F_{t, t+h}=\partial_{h}+\sum_{s=1}^{l} \alpha_{s}^{h} \Delta F_{t-s}+\sum_{s=1}^{l} \beta_{s}^{h} U S_{-} S_{\text {Shock }}{ }_{t-s}+\varepsilon_{h}^{t}
$$

where $h$ denotes the horizon (quarter) of projection, $\Delta F_{t, t+h}$ reports the cumulative change in the world factor of interest (e.g. world output) between quarter $t$ and $t+h$, and $U S$ s shock is the US shock of interest (see below). We use 4 lags for all variables (i.e. $l=4$ ), but results are not sensitive to changes in the number of lags. Since the error term in the local projection framework follows a moving average process by construction, standard errors are always corrected using a Newey and West (1987) estimator.

We restrict attention to four types of US shocks, which have attracted most of the literature on US spillovers and for which we have data over the whole postwar period at a quarterly frequency, namely: (i) US monetary policy shocks, (ii) US fiscal policy shocks, (iii) US policy uncertainty shocks, and (iv) US productivity shocks. Monetary policy shocks are taken from Coibion (2012). ${ }^{29}$ We use Romer and Romer's exogenous tax shocks to measure unanticipated (or exogenous) US tax changes (Romer and Romer, 2010). US policy uncertainty shocks are proxied by changes in the US Economic Policy Uncertainty Index, computed by Bloom and Davis (2016). Finally, US productivity shocks are taken from Basu, Fernald and Kimball (2006) and Fernald (2014). ${ }^{30}$ All variables are available at quarterly frequency since early 1950 's.

\footnotetext{
${ }^{29}$ Since the data starts in 1968 however, we use quarterly changes in the Fed discount rate to proxy for changes in the US monetary policy stance between 1950 and 1968.

${ }^{30}$ We use changes in (utilization-adjusted) US TFP series.
} 
After collecting those shocks, we first confirm that they imply a "textbook" response of US variables. ${ }^{31} \mathrm{We}$ then use them to see how they affect, individually, our estimated world cycles. Since many of those shocks happen at the same time, and in conjunction with other important global shocks (e.g. oil shocks), we also test the robustness of our results to (i) using all US shocks at the same time and (ii) the introduction of measure of exogenous oil supply shocks (Kilian, 2008)). key results are broadly unchanged, however.

Our results generally confirm that US shocks generate significant deviations in real and financial world cycles (Figure 2). We find that US productivity shocks are expansionary for the world, i.e. they are followed by expansions in output, asset prices, credit, and ultimately consumer prices globally. ${ }^{32}$ The response is gradual and peaks after 8 quarters. The impact of US policy uncertainty is also very stark and in line with other recent contributions. ${ }^{33}$ An unanticipated rise in US policy uncertainty is quickly followed by drops in output, share prices and credit around the world.

We also find that US monetary policy contractions are followed by a decline in world output and prices, consistent with previous work. ${ }^{34}$ The response of the world business cycle is negative and significant after two years. However, the effect of monetary shocks on financial variables is more ambiguous. As expected, real equity prices drop on impact following an (unexpected) monetary policy tightening. However, the effect of contractions on the world credit cycle (and real bond yields) is more muted, suggesting that domestic credit markets are relatively isolated from exogenous changes in interest rates in the core. Finally, fiscal consolidations in the US also have a negative effect on the world business cycle. ${ }^{35}$ However, their effect on financial variables is muted.

\footnotetext{
${ }^{31}$ We check that, on our sample (1950-2015), US specific variables (output, prices, credit etc.) have the expected response to US shocks. This is not always the case. For instance, we also used US fiscal spending shocks using Ramey's military news shocks (Ramey and Zubairy, 2018). However, those shocks did not generate a positive response in US output using the post-war period. Therefore, we did not use them in the second stage.

${ }^{32}$ See IMF (2017a) and references therein for similar results and a discussion of the channels through which US technology shocks affect other countries.

${ }^{33}$ Swallow and Cespedes (2013) also find a significant effect of US policy uncertainty in EMs. See Bloom (2014) for a review.

${ }^{34}$ See Ammer et al. (2016) for a recent review of US monetary policy spillovers.

${ }^{35}$ This is in line with many other contributions. See IMF (2017b) for a review.
} 
Figure 2 - Local Projections
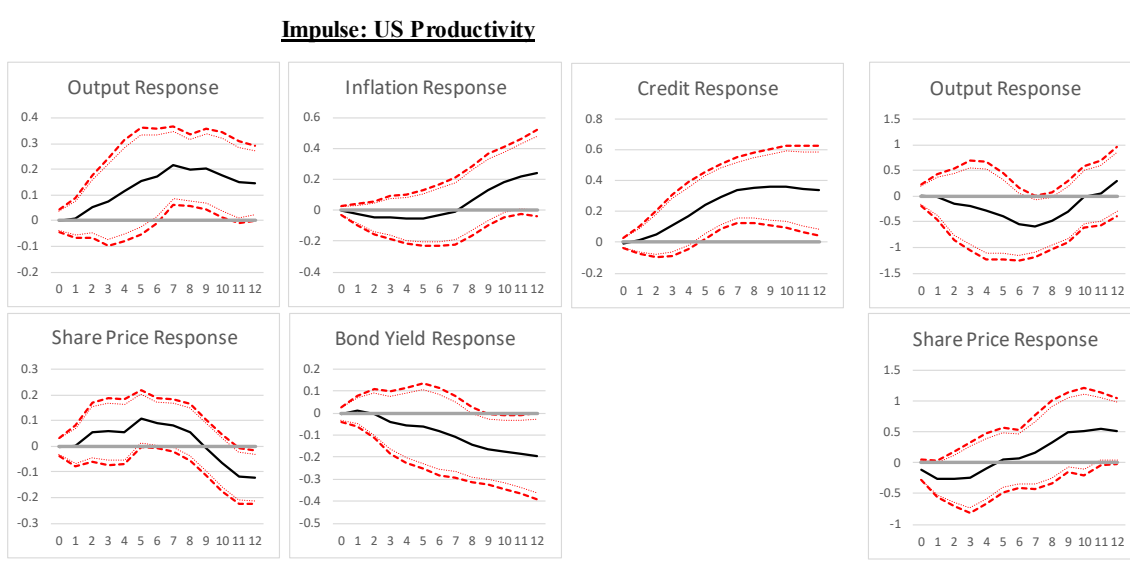

\section{Impulse: US Monetary Policy}

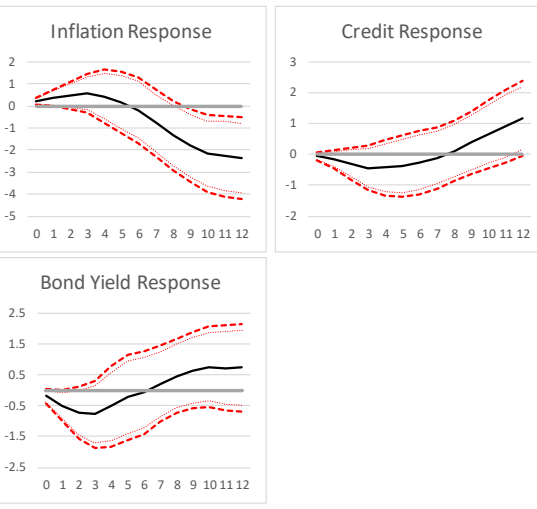

Impulse: US Fiscal Policy

$\underline{\text { Impulse: US Policy Uncertainty }}$
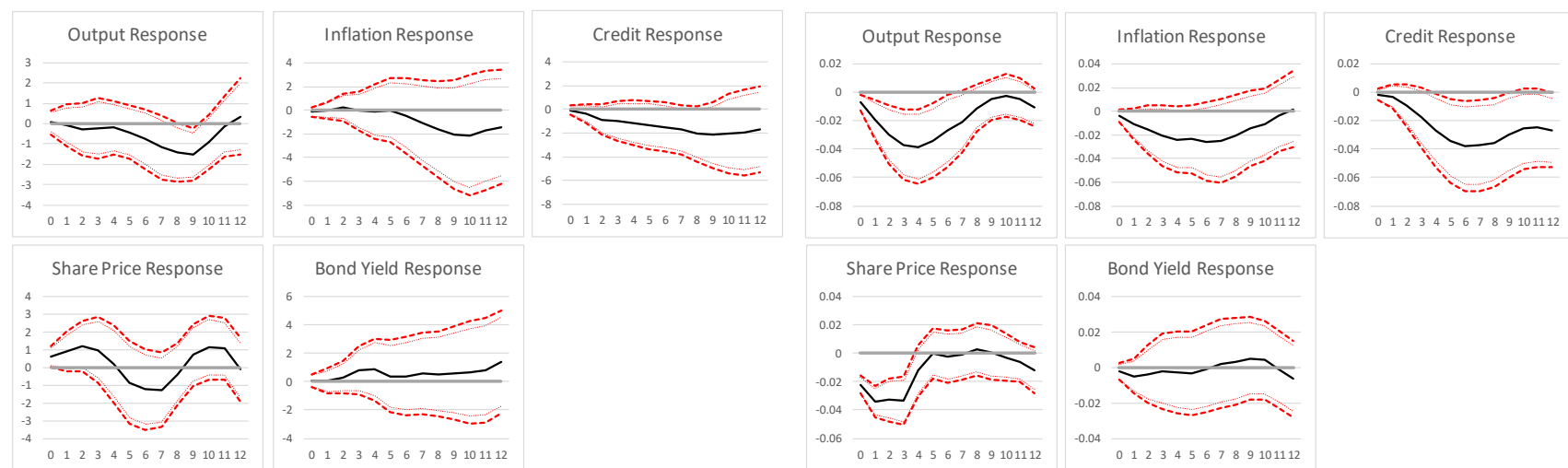

Note: Productivity shocks are "expansionary", i.e. they refer to an increase in US productivity. Other shocks are intended as "contractionary". Monetary and Fiscal shocks refer to (unexpected) monetary policy contractions and increases in tax rates, respectively. A positive change in the policy uncertainty index also refers to an increase in uncertainty. The solid lines report cumulative effects on world cycles. Red dotted lines report confidence intervals $(5 \%$ and $95 \%)$ respectively. Standard errors are corrected for heteroskedasticity and serial correlation. The x-axisreports for the horizon of projection (in quarters). 


\section{How Strong are World Cycles? And Has it Changed?}

We now turn to the strength of world cycles, and its evolution over time. To start, Figure 3 reports the share of (historical) variance explained by each world cycle for the median country in our sample. The right panel reports the same statistics but distinguishes between advanced and emerging countries. In line with other contributions, we find that world cycles account for a significant share of the variance in domestic variables. For instance, the world business cycle accounts for roughly 30 percent of domestic output fluctuations and 50 percent in inflation fluctuations. ${ }^{36}$ However, we also find that world synchronization is much higher in prices (assets and goods) than in quantities (output and credit). With regard to the global financial cycle, the contrast between asset prices and credit is stark: synchronization is three to four times higher in asset prices (bond yields and stock prices) than in credit. Separating AEs from EMs also reveals that advanced economies drive those results. On average, contributions of the world cycles to the median EM economy has been small (around 10 percent across variables). ${ }^{37}$ In other words, world cycles affect disproportionately advanced economies and asset prices.

Figure 3 - Strength
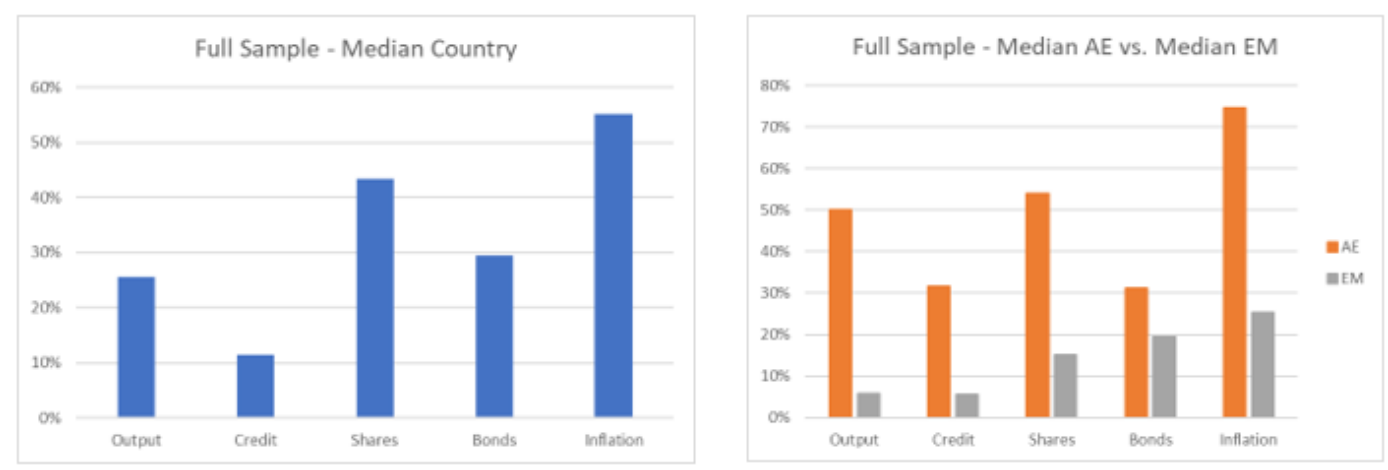

Note: The figures plot the share of variance in domestic variables explained by each corresponding world cycle. Results are reported for the median country in our sample. AE refers to advanced economies

We also unearth new facts regarding the way synchronization at the world level has changed over the last 70 years. Figure 4 reports the median share of variance explained by each world cycle in our sample, distinguishing between the different sub-samples. Two key findings emerge. First, isolating "exceptional" periods of global real and financial shocks is important, since co-movement increases during those periods. This is particularly true for the GFC period, during

\footnotetext{
${ }^{36}$ Once again, those estimations are in line with other empirical contributions using annual data.

${ }^{37}$ Those results are robust if we take out key economies from the ample (e.g. the US). The EM bond sample only consists of South-Africa.
} 
which co-movement in all variables was at record high. Once those periods are isolated however, the average co-movement becomes modest, especially for output and credit (between 10 and 20 percent). We also find that world synchronization has not increased uniformly: although synchronization in asset prices has been on a secular increase since Bretton Woods, the average (or median) impact of world cycles on domestic economies has not changed for output or credit.

Figure 4 - Strength - Sub-Samples

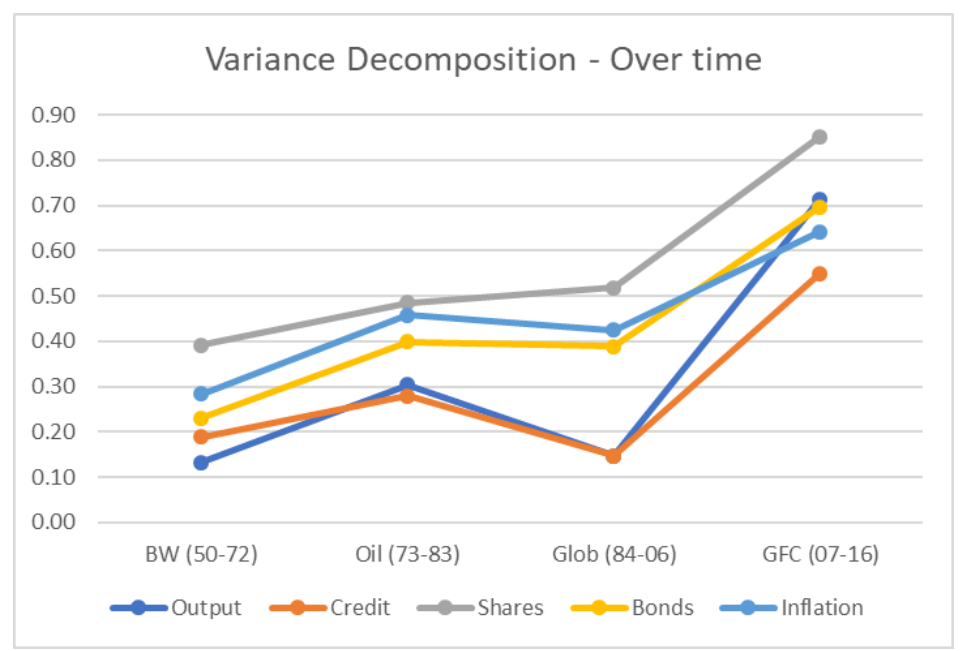

Note: The figures plot the share of variance in domestic variables explained by each corresponding world cycle. Results are reported for the median country in our sample, and for each of the sub-periods defined in Section 3.

Taken together, these results challenge important results. The stability of world output synchronization between Bretton Woods and the Globalization period clearly contradict the findings of the previous literature, for both output and credit (e.g. Kose, Otrok and Whiteman (2008), Cesa-Bianchi et al. (2019)). They also indicate that our appreciation of the strength of world cycles heavily depends on the variable (and period) one looks at. In that respect, the global financial cycle appears much more modest through the lens of credit than asset prices.

\section{Why so stable?}

We finish by exploring the reasons behind the relative stability of world output synchronization over the long run. We first highlight that although the average (or median) output co-movement has been left roughly unchanged between Bretton Woods and the globalization period, the countries that co-move with the rest of the world are not the same. Figure 5 illustrates which countries desynchronized (or re-synchronized) with the world dynamics over the last 70 years. The share of variance explained by the world business cycle, for each country, during the globalization period is plotted against the same share of variance during 
Bretton Woods. The 45-degree line identifies countries that have not changed the way they co-move with the world.

Figure 5: Output Synchronization with the World - Then and Now

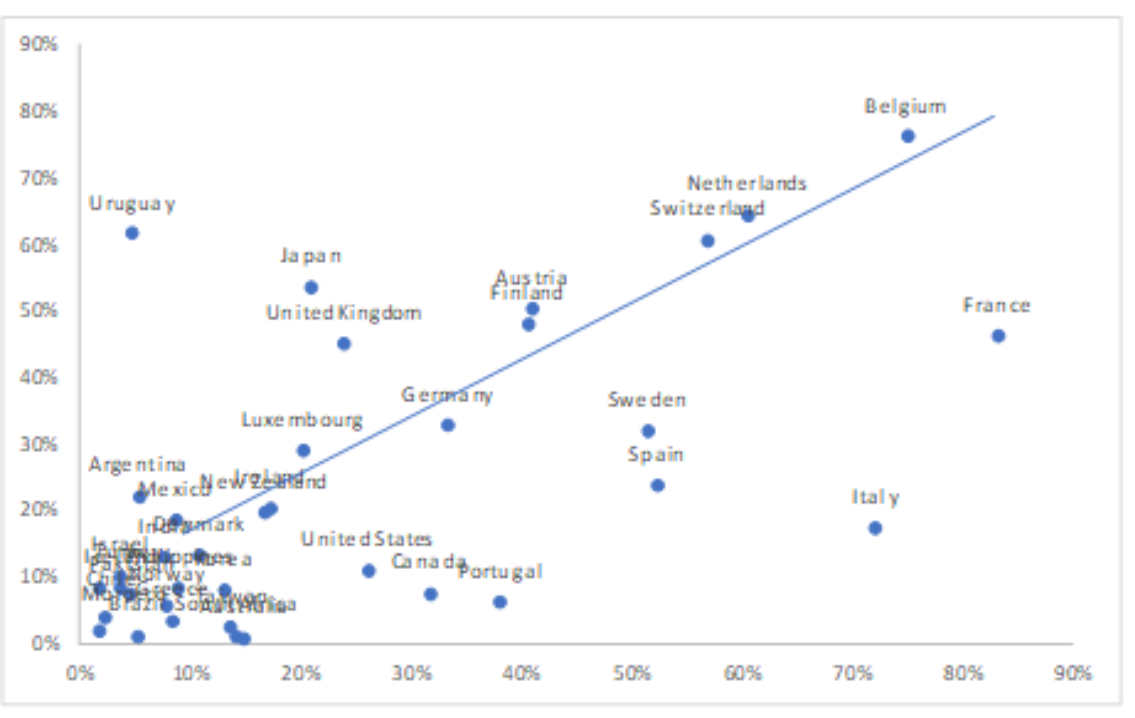

A first striking finding is that the way countries' output co-move with the rest of the world has, for a lot of countries, changed little over the last 70 years. Some countries - such as Netherlands, Finland or Belgium - have always been synchronized with the rest of the world, whereas other (e.g. Norway, Denmark, as well as most emerging markets) display relatively low co-movement with the rest of the world in both periods. Some countries, such as Uruguay, Japan or NewZealand used to co-move more during Bretton Woods than they did 30 years later. In contrast, countries like France, Italy, Spain or to smaller extent the US have resynchronized with the world business cycle. ${ }^{38}$

We explore formally the role of trade integration, financial integration and foreign exchange flexibility in explaining these facts. In practice we use the following panel regressions:

$$
\begin{gathered}
\theta_{i, t}^{W}=\beta_{1} . \text { Trade }_{i, t}+\beta_{2} . \text { Finance }_{i, t}+\beta_{3} . F X_{-} \text {Flex }_{i, t}+\alpha_{i}+d_{t}+\varepsilon_{i, t} \\
t=1,2,3,4 \\
i=1, \ldots, 36
\end{gathered}
$$

\footnotetext{
${ }^{38}$ The very strong synchronization of Italy and France explain partly the results of Kose et. al (2008), which found that a common (G-7) factor explains, on average, a larger fraction of output volatility in the globalization period than it does in the Bretton Woods period. We find that this is not a general result.
} 
Where $\theta_{i, t}^{W}$ designates the share of variance accounted for by the world business cycle for country $i$ in period $t$; Trade $_{i, t}$ captures the level of trade integration of country $i$ in period $t$; Finance $_{i, t}$ captures the level of financial integration of country $i$ in period $t ; F_{-}$Flex $_{i, t}$ measures the degree of flexibility of the exchange rate; $\alpha_{i}$ captures country-fixed effects and $d_{t}$ are time dummies capturing time fixed effects. Period 1 designates the Bretton Woods period; period 2 the oil shock period; period 3 the Globalization period; and period 4 the GFC period.

In practice, we measure trade integration by computing the average ratio of exports plus imports to GDP over each sub-sample for each country. Similarly, we measure financial integration using the average ratio of foreign assets plus foreign liabilities to GDP over each sub-sample for each country. Data are taken from IMF Direction of Trade Statistics and Lane and Milessi-Feretti (2007), respectively. ${ }^{39}$ We control for the exchange rate regime using the (updated) exchange rate classification compiled by Ilzetzki, Reinhart and Rogoff (2017). In practice, for each country in our sample, we average the fine classification (ranging from 1 to 14) over each subperiod. By construction, a higher value of the index indicates greater exchange rate flexibility over that period.

The inclusion of both fixed effects helps us control for the presence of (i) common shocks scaling up all countries at the same time in period 2 and 4 and (ii) country fixed effects, since some countries always co-move less (or more) than others. Although this implies that we cannot say much about the between-variation in the panel, the within-variation is clearly the object of interest in our paper. More importantly, the inclusion of fixed effects allows us to assess, in a more rigorous way, the importance of trade and financial integration in affecting co-movement patterns. To date, important contributions have limited their analysis to crosssection analysis, or panel estimations without the inclusion of fixed effects, implying potentially a significant omitted variable bias in the results (see Kose, Prasad and Terrones (2003)).

Table 1 reports the results. Standard errors are clustered by country in all estimations. Columns 1 presents results for the baseline regression. Columns 2 and 3 present results when financial integration and trade integration measures are interacted with time dummies to investigate the presence of potential asymmetries during periods of common shocks. This allows us to isolate the effect of financial

\footnotetext{
${ }^{39}$ Given our focus on spillovers and co-movement and line with the empirical literature, we focus our attention on de facto measures of openness - expressed as percent GDP - rather than de jure measures. The latter have been shown to be at odds with actual capital flows, in particular under Bretton Woods controls, a period during which capital controls were not fully binding. In addition, one they reach their maximum, de jure measures do not distinguish between different degrees of financial integration. In our context, this implies that all advanced countries in the last period display the same level of integration, although some advanced countries are two to three times more integrated than others (based on our de facto measure).
} 
integration in normal times from its effect in times of financial crisis. Although the number of observations used for estimation is small (144), the panel regression yields striking results, some of which are well connected to recent empirical contributions. First, trade integration tends to increase co-movement with the rest of the world. Second, financial integration has, on average, a negative impact on the synchronization of domestic output to the world business cycle. However, this average effect conceals an asymmetric effect: when using interaction terms with the GFC period, the coefficient is positive, implying that more financially connected countries co-move more during financial crisis. However, the total (net) effect remains negative. Third, we do not find that FX flexibility has an impact on how domestic output connect with the world cycle.

Table 1: Determinants of World Business Cycle Synchronization

\begin{tabular}{lccc}
\hline \hline & $(1)$ & $(2)$ & $(3)$ \\
\hline Trade Openness & $0.13^{* *}$ & $0.19^{* * *}$ & $0.153^{* * *}$ \\
Financial Openness & $-.07^{* *}$ & $-.09^{* *}$ & $-.07^{* *}$ \\
FX Flexibility & 0.01 & 0.01 & 0.007 \\
OIL & $0.08^{* *}$ & $0.08^{* *}$ & 0.119 \\
GFC & $0.40^{* * *}$ & 0.07 & $0.371^{* * *}$ \\
& & & \\
Interactions & & & \\
GFC x Financial Openness & & $0.06^{* *}$ & \\
GFC x Trade Openness & & 0.001 & \\
Oil Shock x Financial Openness & & & 0.01 \\
Oil Shock x Trade Openness & & & $-.002^{*}$ \\
\hline Country FE & Yes & Yes & Yes \\
$\mathrm{N}$ & 144 & 144 & 144 \\
R- squared & 0.557 & 0.569 & 0.530 \\
\hline \hline
\end{tabular}

Note: The dependent variable is the share of variance of domestic output accounted for by the world business cycle in each of the four periods. All estimations include country fixed effects. Standard errors are clustered at the country level. ${ }^{*}{ }^{* *},{ }^{* * *}$ refer to significance at 10 percent, 5 percent and 1 percent, respectively.

\section{RobUSTNESS}

We explore the robustness of our historical comparisons to different cutoffs. First, we re-estimate cycles and variance decompositions using 15 -year rolling windows. Figure 6 reports the (median) share of variance explained by the different world cycles over these different windows. The date below reports the central year of the window, so that year 2000 refers to the period between 1992-2008. We find that our key findings do not depend on specific windows. For instance, for both 
output and credit, the stability in the strength of the world cycles we identify is not driven by very low values during the early 80 's, when integration was still in its infancy. However, the impact of the GFC on both measures is very stark: for both output and credit, the measures rise suddenly when the 2007-2009 period enters the sample, giving the impression of a "break" in measures of synchronization. This broad pattern is also true for both AEs and EMs. This view contrasts with the rise in synchronization in asset prices, which starts trending upwards in the early 90's for all countries in our sample.

Finally, we find that the post GFC environment is not dramatically different from the Pre-GFC (i.e. the nature of global spillovers has not changed since the end of the crisis). To illustrate that finding, Figure 7 plots the equivalent of Figure 4, but breaking down the last period into the GFC and the post-GFC period. Once again, we confirm (i) the strong decoupling between prices and quantities and (ii) that the GFC years represent an outlier when it comes to credit and output synchronization. Although the 2010-2016 sample is small - and marked by global events such that the European debt crisis -, excluding 2008/2009 shows that output and credit synchronization measures have almost reverted to their pre-crisis level. In contrast, synchronization in prices remains high. 
Figure 6: Rolling Windows
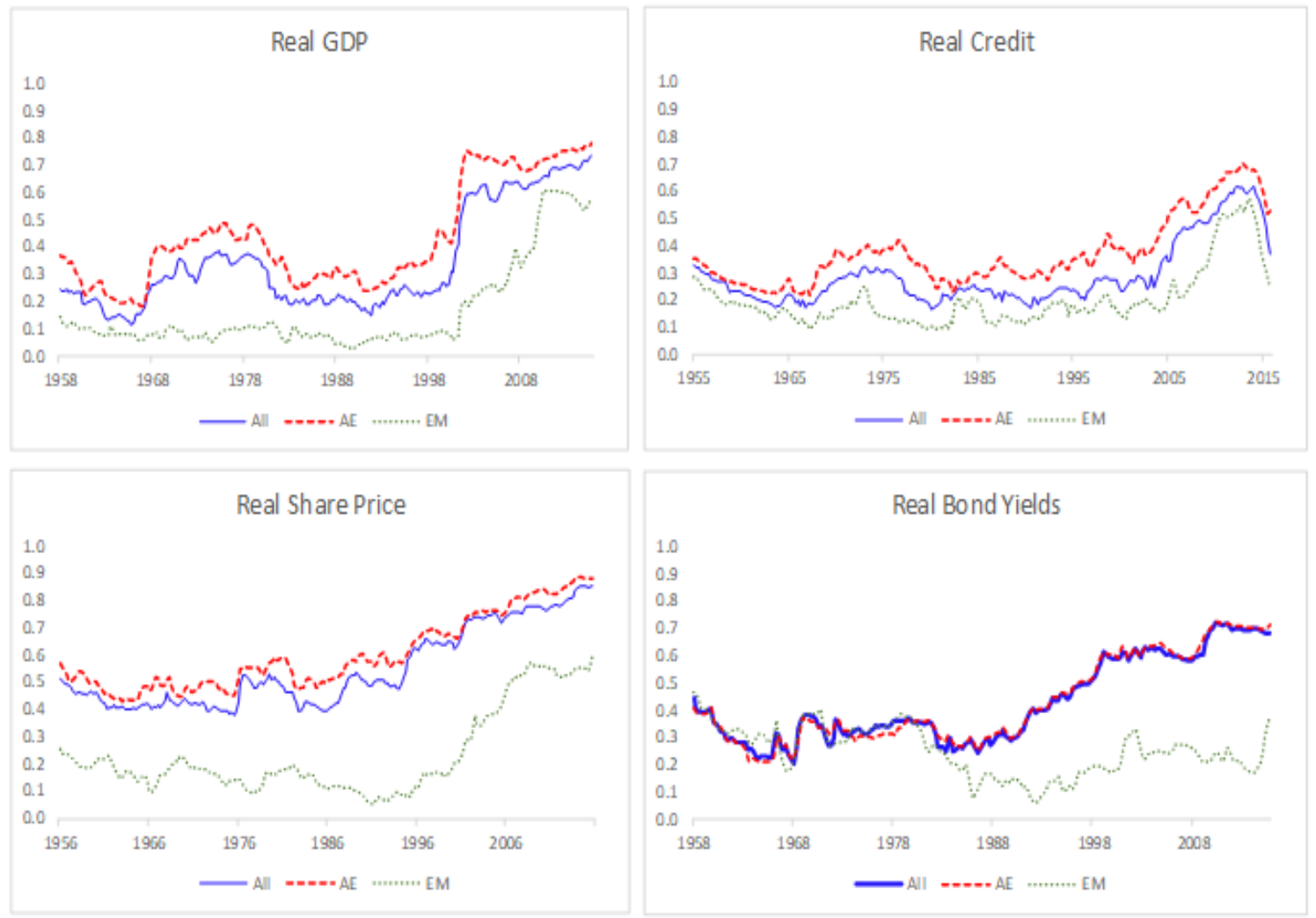

Note: The figures report the evolution of variance decompositions for the madian country (All, AE or EM) over 15-year rolling windows. The upper left (right) panal reports results us ing real GDP (credit). The lower left (right) panel reports stock prices (bond yialds). The bond yield EM sample is limited to South Africa. The date on the $\mathrm{x}$-axis reports the central year of the window, 30 that year 2000 refers to the period between 1992-2008.

Figure 7 - GFC exclusion

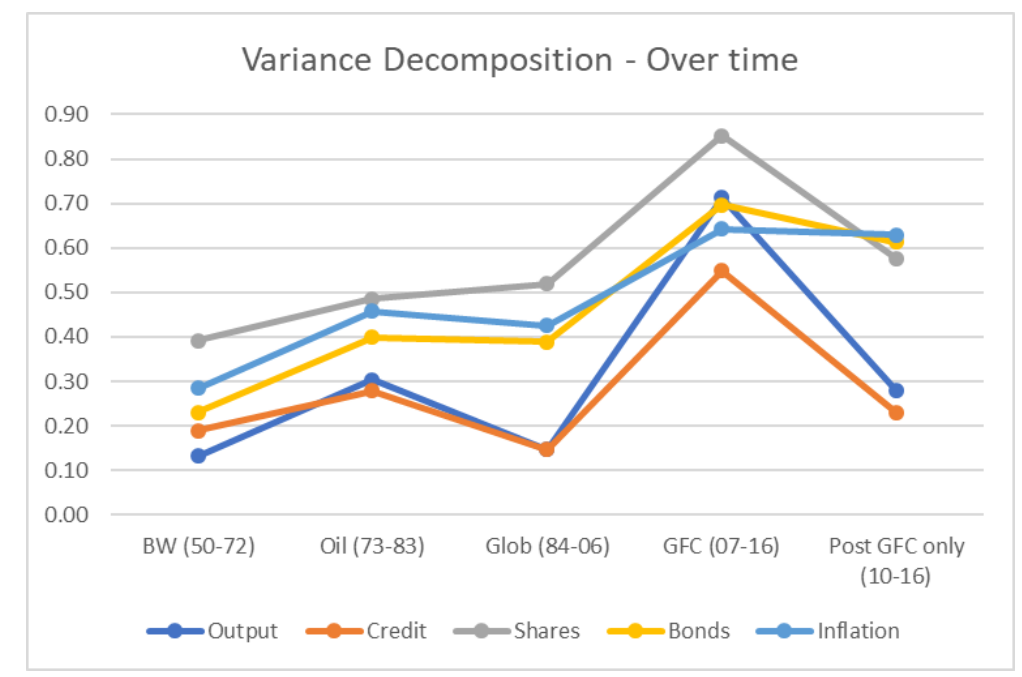

Note: The figure plots the share of variance in domestic variables explained by each corresponding world cycle. Results are reported for the median country in our sample, and for each of the sub-periods defined in Section 3. The last period - Post GFC only - ranges from 2010 to 2016. 


\section{Conclusion}

Economists studying macro-financial linkages usually face a statistical "trilemma", where they need to choose between frequency (quarterly vs. annual), coverage (AEs vs. EMs) and length of coverage. Using IMF archives, we compile a new macro-financial quarterly database for both advanced and emerging economies since 1950 and use it to highlight several new facts regarding the strength of real and financial global cycles, and their evolution over time. Inter alia, we show that although world cycles exist and are driven by the US, their strength vary widely across variables and countries. Overall, world cycles, both real and financial, affect mostly advanced economies and asset prices. Asset price synchronization, in particular, seems to be a durable feature of the global financial system. In contrast, we find that the synchronization of output and credit at the world level has been relatively low and stable over the whole post-war period, at least during normal times. Among other things, this clearly highlights the uniqueness of the GFC in the macro-financial history of the world; a time of unprecedented synchronization at the global level. It also suggests that the drivers of synchronization during the GFC might be different from the ones behind "normal" international cycles.

Finally, our research raises key questions regarding the importance of the global financial cycle. The coexistence of a strong co-movement in asset prices but modest co-movement in key policy targets, such as output and credit, points to more policy autonomy than expected, especially in EMs. Looking at credit in particular, a financial variable that is under more direct control of policymakers than asset prices, clearly suggests that local credit conditions for the private sector are not directly tied to the external environment (or to US conditions). This finding suggests that the pass-through from external conditions to local credit crucially depends on the institutional and financial landscape in the domestic economy. ${ }^{40}$ It also questions the macroeconomic relevance of effects previously identified in the literature. Although there is ample evidence that capital flows and asset prices "react" to policies in core countries, foreign capital remains small relative to domestic bank lending. ${ }^{41}$ We leave a comprehensive investigation of all these aspects for future research.

\footnotetext{
${ }^{40}$ Even when banks rely on dollar funding, high net interest margins, which are common in emerging markets, could dampen the impact of changes in foreign interest rates on the domestic private sector credit. Financial repression, through restrictions on interest rate or credit allocation, could also mitigate the impact of external conditions.

${ }^{41}$ Portfolio investments and direct cross-border banking flows are limited for most countries in our sample. In our sample and based on BIS statistics, more than 85 percent of total credit to the private sector still goes though domestic banks in the median EM (and more than 75\% in advanced countries).
} 


\section{References}

Ammer, J M De Pooter, C. Erceg, and S. Kamin, 2016. "International Spillovers of Monetary Policy,", IFDP Notes, Board of Governors of the Federal Reserve.

Auer, R. A., A. Levchenko, and P. Sauré, 2017. “International Inflation Spillovers through Input Linkages." NBER Working Paper 23246, National Bureau of Economic Research, Cambridge, MA.

Barakchian, S. Mahdi, and C. Crowe, 2013. "Monetary policy matters: Evidence from new shocks data" Journal of Monetary Economics 60.8 : 950-966.

Basu, S., Fernald, J.G., Kimball, M.S., 2006. "Are technology improvements contractionary?" American Economic Review. 96, 1418-1448.

Bernanke, Ben S., and I. Mihov, 1998. "Measuring monetary policy." The Quarterly Journal of Economics 113.3 (1998): 869-902.

Bloom, Nicholas, 2014. "Fluctuations in Uncertainty", Journal of Economic Perspectives, 28, 153-176

Bräuning, Falk, and V. Ivashina, (forthcoming) "U.S. Monetary Policy and Emerging Market Credit Cycles." Journal of Monetary Economics.

Calvo, Guillermo A., and C. M. Reinhart, 2002. "Fear of floating." The Quarterly Journal of Economics 117.2: 379-408.

Carriere-Swallow, Yan and L. Cespedes, 2013. "The Impact of Uncertainty Shocks in Emerging Economies”, Journal of International Economics, 90, 316-325

Cerutti, Eugenio, S. Claessens, and A. K. Rose, 2017. "How Important is the Global Financial Cycle? Evidence from Capital Flows," IMF Working Paper No. 17/193, International Monetary Fund, Washington, DC.

Cesa-Bianchi, Ambrogio, 2013. "Housing Cycles and Macroeconomic Fluctuations: A Global Perspective" Journal of International Money and Finance, Vol. 37, pp. 215-238.

Cesa-Bianchi, Ambrogio, L. Cespedes, and A. Rebucci, 2015. "Global Liquidity, House Prices, and the Macroeconomy: Evidence from Advanced and 
Emerging Economies," Journal of Money, Credit and Banking, Vol. 47: S1, pp. 301-335.

Cesa-Bianchi, A., E. Martin and G. Thwaites, 2019. "Foreign Booms, Domestic Busts: The Global Dimension of Banking Crises". Journal of Financial Intermediation, Volume 37, Pages 58-74.

Cesa-Bianchi, Ambrogio, J. Imbs, and J. Saleheen, 2019. "Finance and Synchronization." Journal of International Economics 116: 74-87.

Chinn, M.D., Ito, H., 2006. "What Matters for Financial Development? Capital Controls, Institutions, and Interactions". Journal of Development Economics 81(1), 163-192.

Chow, G., C., and Lin, A., 1971. "Best Linear Unbiased Interpolation, Distribution and Extrapolation of Time Series by Related Series," The Review of Economics and Statistics, 53, 372-375.

Ciccarelli, M., and B. Mojon. 2010. "Global Inflation.” Review of Economics and Statistics 92 (3): 524-35.

Claessens, Stijn, A. Kose, and M. E. Terrones, 2012. "How Do Business and Financial Cycles Interact?” Journal of International Economics, Vol. 87:1, pp. 178-190.

Coibion, O., 2012. "Are the effects of monetary policy shocks big or small? American Economic Journal, Macroeconomics. 4 (2), 1-32.

Dedola, Luca, G. Rivolta, L. Stracca, 2017. "If the Fed Sneezes, Who Catches a Cold?" Journal of International Economics, Volume 108, Supplement 1, Pages S23-S41.

Dembiermont, Drehmann M, and Muksakunratana S, 2013. "How much does the private sector really borrow - a new database for total credit to the private non-financial sector," BIS Quarterly Review, Bank for International Settlements, March.

Doyle, Brian M. and Faust, Jon, 2005. "Breaks in the Variability and Co-movement of G-7 Economic Growth", The Review of Economics and Statistics, vol. 87(4), p. 721-740. 
Duval, Romain, N. Li, R. Saraf and D. Seneviratne, 2015. "Value-Added Trade and Business Cycle Synchronization", Journal of International Economics.

Fernald, J.G., 2014. “A Quarterly, Utilization-Adjusted Series on Total Factor Productivity." Federal Reserve Bank of San Francisco Working Paper 2012-19.

Ha, J., M. A. Kose, and F. Ohnsorge. 2019. Inflation in Emerging and Developing Economies: Evolution, Drivers and Policies. Washington, DC: World Bank.

Ha, J., M. A. Kose, C. Otrok, and E. S. Prasad, 2017. "Global Macro-Financial Cycles and Spillovers." Paper presented at the 18th Jacques Polak Annual Research Conference, International Monetary Fund, November 2-3, Washington, DC, November 2-3.

Heathcote, Jonathan, F. Perri, 2004. "Financial globalization and real regionalization", Journal of Economic Theory, vol. 119 (1), p.207-243

Imbs, Jean, 2004. "Trade, Finance, Specialization, and Synchronization", The Review of Economics and Statistics, vol. 86 (3), p.723-734.

Ilzetzki, Ethan, C. M. Reinhart, and K. Rogoff, 2017. "Exchange Rate Arrangements in the 21st Century: Which Anchor Will Hold?", National Bureau of Economic Research, Working Paper 23134, February 2017.

International Monetary Fund (IMF), 2013. "Dancing Together? Spillovers, Common Shocks, and the Role of Financial and Trade Linkages", World Economic Outlook, October, Chapter 3.

International Monetary Fund (IMF), 2017. "Gone with the Headwinds: Global Productivity”, IMF Staff Discussion Note, 2017.

Jordà, Oscar, M. Schularick, and A. M. Taylor, 2017. "Macrofinancial History and the New Business Cycle Facts." NBER Macroeconomics Annual 2016, volume 31, edited by Martin Eichenbaum and Jonathan A. Parker. Chicago: University of Chicago Press.

Jordà, Oscar, M. Schularick, A. M. Taylor, Felix Ward, 2019. “Global Financial Factors and Risk Premiums", IMF Economic Review 2019, forthcoming 
Kalemli-Ozcan, Sebnem, E. Papaioannou, and F. Perri, 2013. "Global banks and crisis transmission", Journal of International Economics, vol.89(2), p.495510.

Kalemli-Ozcan, Sebnem, E. Papaioannou and J-L. Peydro, 2013. "Financial Regulation, Financial Globalization, and the Synchronization of Economic Activity", Journal of Finance, vol. 68(3).

Kilan, Lutz, 2008. "Exogenous Oil Supply Shocks: How Big Are They and How Much Do They Matter for the U.S. Economy? Review of Economics and Statistics, 90(2), 216-240, May 2008.

Kose, Ayhan, C. Otrok, C. H. Whiteman, 2003. "International business cycles: world, region, and country-specific factors", American Economic Review, vol. 93 (4), p.1216-1239.

Kose, Ayhan, C. Otrok, C. H. Whiteman, 2008. "Understanding the evolution of world business cycles”, Journal of International Economics, vol.75 (1), p. $110-130$.

Kose, Ayhan, E. Prasad, M. Terrones, 2003. "How Does Globalization Affect the Synchronization of Business Cycles?", American Economic Review, vol. 93(2), p. 57-62.

Kose, Ayhan, E. Prasad, M. Terrones, 2006. "How do trade and financial integration affect the relationship between growth and volatility?", Journal of International Economics, vol. 69(1), p. 176-202.

Kose, Ayhan, E. Prasad, K. Rogoff, S-J. Wei, 2006. "Financial Globalization: A Reappraisal", IMF Working Papers 06/189, International Monetary Fund.

Lane, Philip R. and G. M. Milesi-Ferretti, 2007, "The external wealth of nations mark II: Revised and extended estimates of foreign assets and liabilities, 1970-2004”, Journal of International Economics, vol.73(4), p. 223-250.

Lumsdaine, Robin L. and E. S. Prasad, 2003, "Identifying the Common Component of International Economic Fluctuations: A New Approach", Economic Journal, vol.113(4), p. 101-127. 
Miranda-Agrippino, S. and H. Rey, 2015. "US Monetary Policy and The Global Financial Cycle”. NBER Working Papers 21722.

Monnet, Eric, and D. Puy. 2016. "Has Globalization Really Increased Business Cycle Synchronization?”. IMF Working Papers No. 16/54. International Monetary Fund.

Mumtaz, Haroon, Simonelli, Saverio, Surico, Paolo, 2011, "International comovements, business cycle and inflation: A historical perspective". Review of Economic Dynamics, vol. 14 (1), p.176-198.

Obstfeld, Maurice, 1994. "Risk-Taking, Global Diversification, and Growth." American Economic Review, vol.84(5), p.1310-1329.

Obstfeld, Maurice, and Alan M. Taylor, 2004. Global capital markets: integration, crisis, and growth, Cambridge, Cambridge University Press.

Quinn, Dennis P., and A. M. Toyoda, 2008. "Does capital account liberalization lead to growth?" The Review of Financial Studies 21.3: 1403-1449.

Ramey, V, and Zubairy, S. 2018, "Government Spending Multipliers in Good Times and in Bad: Evidence from U.S. Historical Data" Journal of Political Economy.

Reinhart, Carmen M., and Kenneth S. Rogoff. 2004. "The modern history of exchange rate arrangements: a reinterpretation." Quarterly Journal of Economics 119.1 : 1-48.

Rey, Hélène, 2013, "Dilemma not Trilemma: The Global Financial Cycle and Monetary Policy Independence," NBER Working Paper No. 21162, National Bureau of Economic Research, Cambridge.

Rey, Helene, 2015, "International Channels of Transmission of Monetary Policy and the Mundellian Trilemma", Mundell Fleming Lecture, IMF Economic Review.

Romer, Christina D., and D. H. Romer, 2002, “A Rehabilitation of Monetary Policy in the 1950's", American Economic Review, vol. 92(2), p.121-127.

Romer, Christina D., and D. H. Romer, 2004. "A new measure of monetary shocks: Derivation and implications." American Economic Review 94.4: 10551084. 
Romer, Christina D., and D. H. Romer, 2010. "The macroeconomic effects of tax changes: estimates based on a new measure of fiscal shocks". American Economic Review. 100, 763-801.

Romer, Christina D., and D. H. Romer. "New evidence on the aftermath of financial crises in advanced countries." American Economic Review 107.10 (2017): 3072-3118.

Stock, James H. and Watson, Mark W. 2005, "Understanding Changes in International Business Cycle Dynamics", Journal of the European Economic Association, vol. 3(5), p. 968-1006.

Williamson, John., 1985, "On the system in Bretton Woods", The American Economic Review, p. 74-79. 


\section{APPENDIX I - DATA}

We construct five variables for a large cross section of countries at a quarterly frequency: (i) GDP (ii) Credit (iii) Prices, (iv) Stock Prices and (v) Longterm Bond Yields. Although some specificities apply (see below), we follow the same procedure for all series. We first collect the whole universe of official statistics provided by local authorities for each variable. We then use the IFS archives to extend all series in the past, after making sure definitions match. ${ }^{42}$ Table 1 below provides the final country coverage for each data series (black indicates that the data is available for that country over the whole sample).

In practice, consumer prices are reconstructed using the "cost of living" index (line 66 in IFS). Stock prices are based on the "share price index" collected (line 61 or above in IFS). When this index is not available, we use the "Industrial share price" as a proxy for the overall index. Bond yields refer to average yields to maturity on (central) government bonds issues with lives of least 7 years (line 62 in IFS). With very few exceptions, we find that our series move in tandem with sources reporting the same data at annual frequency, suggesting that we are tracking the same data currently used in the literature, albeit at a higher frequency and for a much broader set of countries. For instance, figures below plot stock price growth based on our IFS stock index (in green) in Norway and Denmark against annual stock price growth using data from Jorda et al. (2017), which are available at annual frequency. The blue part of the IFS line identifies the part of that is already covered by official data. Overall, the 35 years we add using quarterly data (between 1950 and 1985) align very well with annual data. Very similar findings appear when using bond yields or inflation across all countries (when such a comparison is possible).

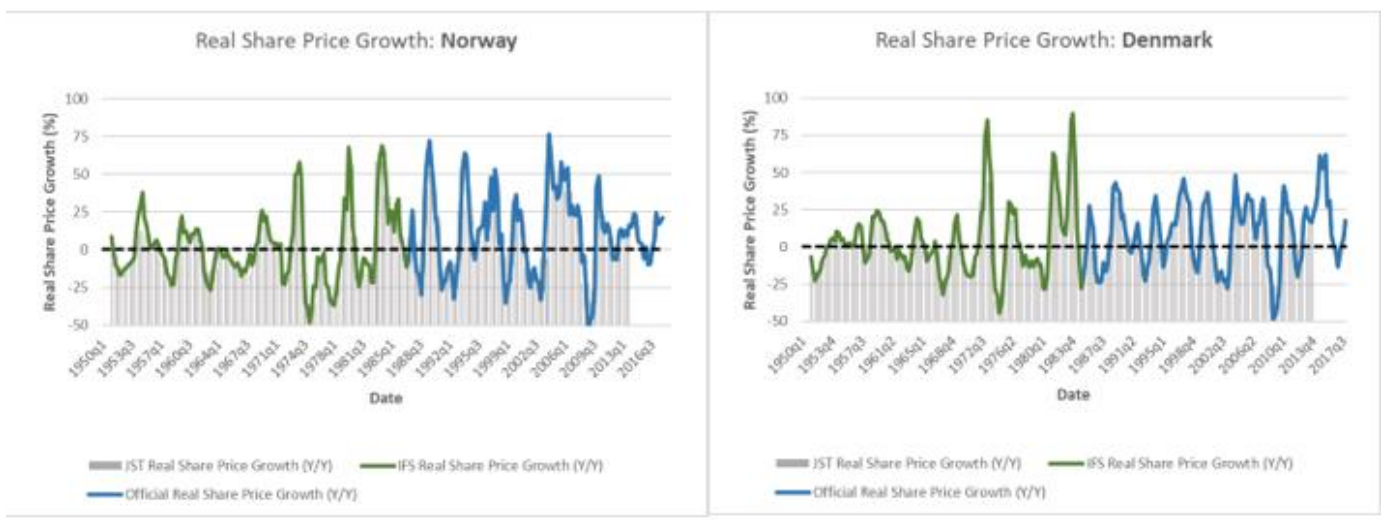

42 To be more precise, we check that definitions match (on paper) and that they also report the same variations (i.e. IFS statistics and Official Statistics match de facto when both are available). 
We now turn to GDP and credit for which the extension exercise is more involved. We address them in turn.

\section{(i) $\underline{\text { Credit }}$}

In line with most contributions on credit cycles (e.g. Claessens et. al, 2011)), we use the IFS "claims on the private sector from domestic banks" (IFS line 32d) as our definition of domestic credit. This definition is equivalent to the" Bank credit to the Private Non-Financial Sector" assembled by the BIS (also used in the literature) and excludes foreign credit and credit from other institutional sectors (e.g. the government or non-banks). Compared to other data, credit aggregates are subject to a significant number of breaks throughout history, however. When breaks in credit series happen, those breaks are well-documented in the volumes and, at least for a couple quarters, values of the same data series are reported under the old and the new definition in different IFS vintages. This allows us to chain different data series and create long series without breaks. In practice, we are very close to the BIS long credit dataset (Dembiermont, 2013), which is the most comprehensive dataset of (long) credit statistics. Once again, our series based on historical IFS data track closely other sources at annual frequency. For instance, figures below report the annual credit growth based on our quarterly data (in green) against the annual data from Jorda et al (2017) (in gray) for Spain and Italy. The blue line reports the part of our data that is also covered by the BIS.
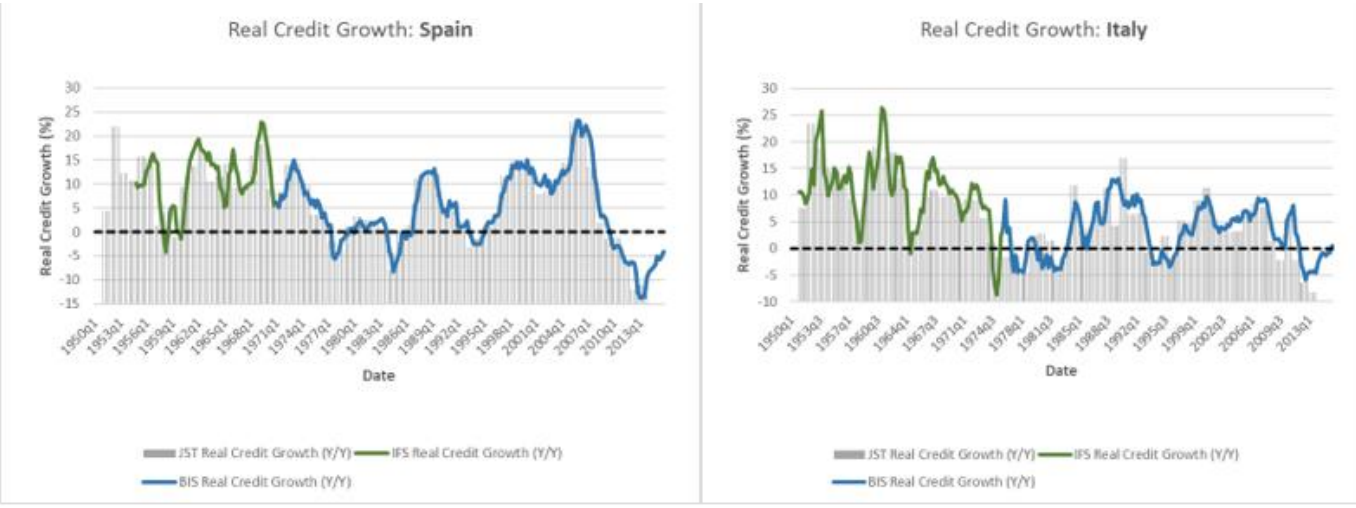

(ii) Gross Domestic Product

Except for a few countries (US, France or the UK), long quarterly GDP series do not exist. Official Quarterly GDP series start in the mid 80's for a few countries and for most countries in the early 90's. To circumvent this issue, we use temporal disaggregation methods to create "synthetic" quarterly GDP series based on (i) annual GDP series and (ii) quarterly Industrial Production data (Chow Lin, 1971). Annual GDP series are taken from Penn World Tables. Industrial (or 
Manufacturing) Production data are taken from historical IFS volumes (IFS line 67).

In spirit, the temporal disaggregation method simply allocates the annual GDP into quarters using the (quarterly) IP as a guide. Since the sum of quarters must match the annual GDP number however, annual growth rates can never deviate, on average over the year, from the growth imposed by annual GDP series. As a result, temporal disaggregation methods use the accuracy of Industrial Production in tracking output a high frequency, under the constraints imposed by annual GDP numbers. This explains that such methods are extensively used to create long GDP statistics, such as the one produced by the OECD. To illustrate the power of this method, the figure below plots the official growth rates based on official quarterly data in the US (BEA) and France (INSEE), in gray, against growth derived using our synthetic GDP data, in green. We find that the two series correlate extremely well. We also report the result of the disaggregation for two other countries (Japan and Mexico) and plot growth rates derived using OECD data. We find that our growth rates track both official and OECD GDP growth rates very closely. However, for Mexico, our data reveals that historical OECD data are not always based on actual output data. Beyond extending the coverage of traditional sources, using historical Industrial Production (IP) directly from the IFS archives therefore also eliminates GDP series based on simple linear interpolations.
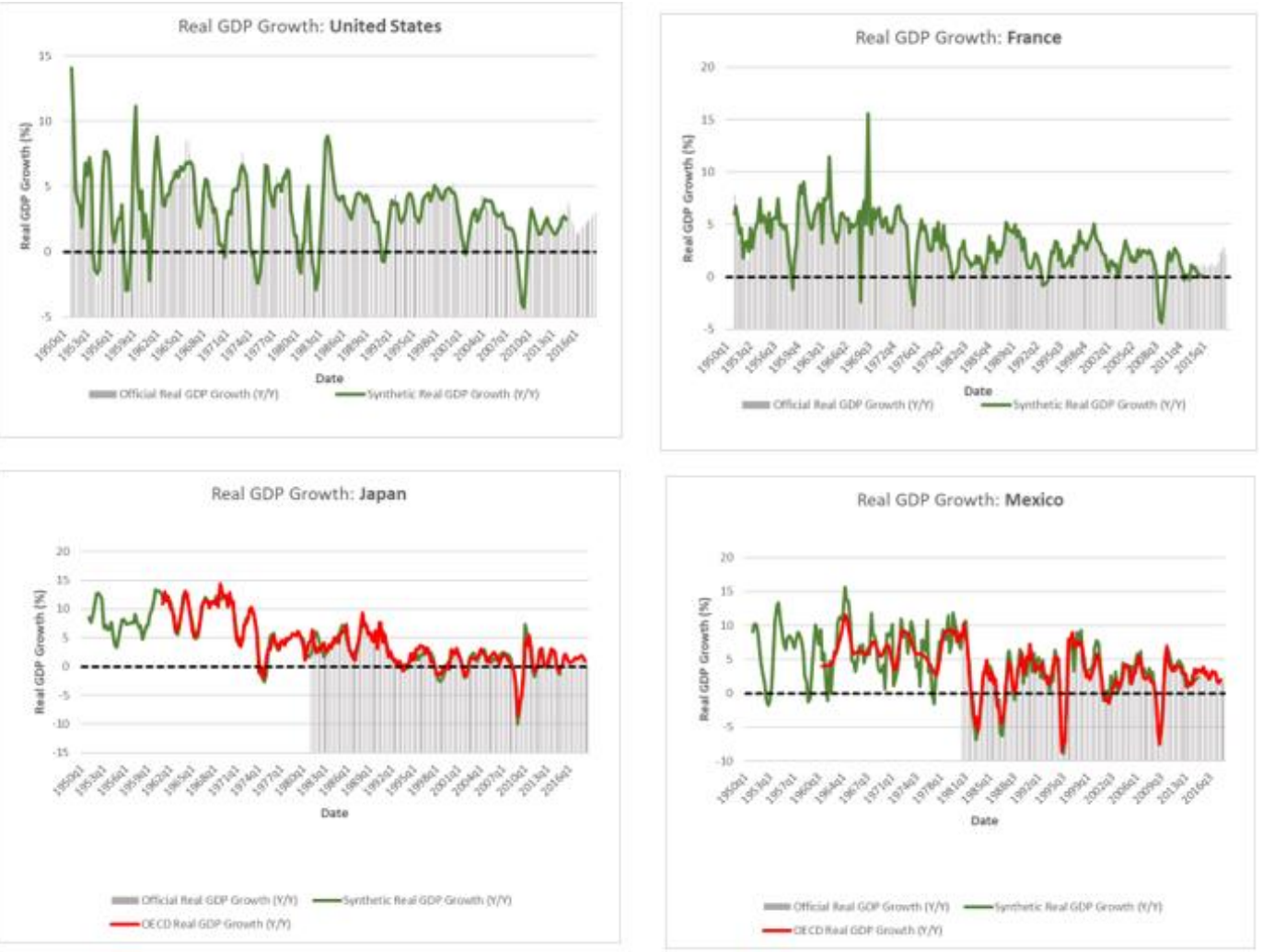
Final Coverage

\begin{tabular}{|c|c|c|c|c|c|}
\hline Country & GDP & Credit & Stock Prices & Bond Yields & Prices \\
\hline Argentina & & $Q_{2}$ & & & $\mathrm{Q}$ \\
\hline Australia & & D Q1 & & & $Q$ \\
\hline Austria & & 0 Q1 & & & $Q$ \\
\hline Belgium & & 0 Q4 & & & Q1 \\
\hline Bolivia & & 0 Q4 & & & $Q$ \\
\hline Brazil & & $0 \mathrm{Q}$ & & & \\
\hline Canada & & 0 Q1 & & & 01 \\
\hline Chile & & $0 Q 4$ & & & QI \\
\hline Colombia & & $2 Q_{4}$ & & & \\
\hline Costa Rica & & 0,4 & & & \\
\hline Cyprus & & $8 \mathrm{Q1}$ & & & 701 \\
\hline Denmark & & Q1 & & & $Q 1$ \\
\hline El Salvador & & & & & $Q$ \\
\hline Finland & & $14=$ & & & $Q$ \\
\hline France & & $0 Q_{1}$ & & & $\mathrm{OQ1}$ \\
\hline Germany & & 50 Q1 & & & Q1 \\
\hline Greece & & $3 Q_{4}$ & & & $Q$ \\
\hline Guatemala & & $4 \mathrm{Q}_{1}$ & & & \\
\hline Honduras & & $50 Q 4$ & & & 04 \\
\hline Iceland & & 55 Q1 & & & $5 Q$ \\
\hline India & & 0 Q1 & & & 01 \\
\hline Ireland & & $10 \mathrm{Q1}$ & & & Q Q1 \\
\hline Israel & & $51 \mathrm{Q}$ & & & $1 \mathrm{Q} 4$ \\
\hline Italy & & 50 Q1 & & & 0 Q1 \\
\hline Japan & & Q1 & & & Q1 \\
\hline Korea & & & & & a \\
\hline Luxembourg & & 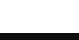 & & & Q1 \\
\hline Malaysia & & & & & \\
\hline Malta & & & & & \\
\hline Mexico & & $Q_{1}$ & & & Q1 \\
\hline Morocco & & $59 Q_{1}$ & & & Q Q1 \\
\hline Netherlands & & 0 Q1 & & & Q \\
\hline New Zealand & & 0 Q1 & Q & & Q1 \\
\hline Norway & & 0 Q1 & & & Q1 \\
\hline Pakistan & & 0 Q4 & & & Q. \\
\hline Peru & & Q4 & & & \\
\hline Philippines & & $Q_{4}$ & & & $\mathrm{Q}$ \\
\hline Portugal & & 0,01 & & & Q \\
\hline South Africa & & $50 Q_{4}$ & & & $\mathrm{OQ1}_{1}$ \\
\hline Spain & & IQ4 & & & Q1 \\
\hline Sweden & & 0 Q1 & $50 \mathrm{Q}$ & & Q1 \\
\hline Switzerland & & $50 Q_{1}$ & & & Q \\
\hline Taiwan & & $17 Q 1$ & & & Q \\
\hline Thailand & & Q4 & & & Q \\
\hline Turkey & & $0 Q_{4}$ & & & Q \\
\hline United Kingdom & & 50 Q1 & & & Q1 \\
\hline United States & & $Q_{1}$ & & & \\
\hline Uruguay & & & & & \\
\hline
\end{tabular}


APPENDIX II - FIGURES AND TABLES

World Cycles - Supplement

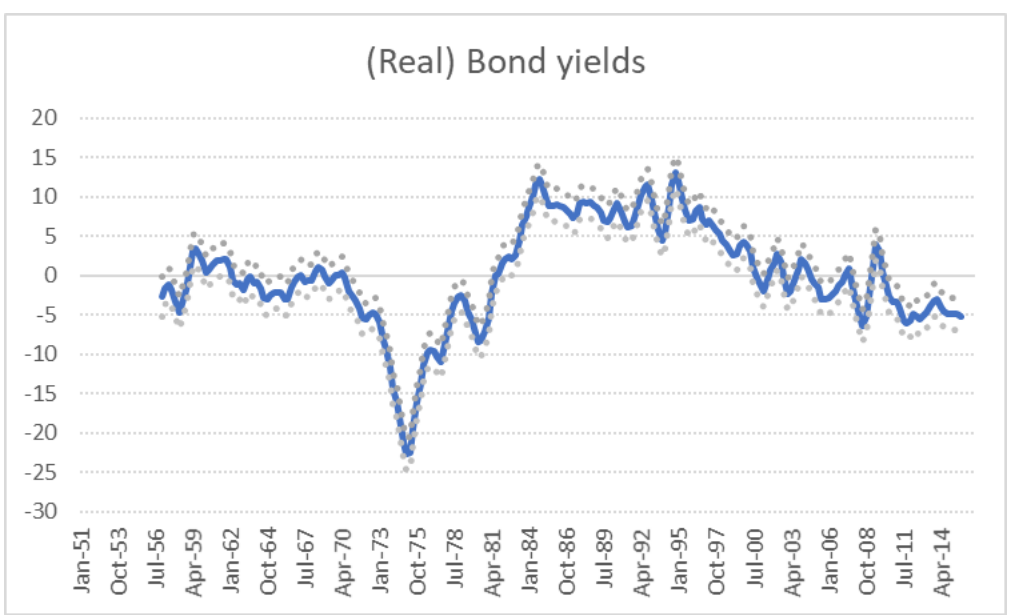

CInternational Monetary Fund. Not for Redistribution 